NBER WORKING PAPER SERIES

\title{
INTERNATIONALIZATION AND THE EVOLUTION OF CORPORATE VALUATION
}

\author{
Ross Levine \\ Sergio L. Schmukler \\ Working Paper 11023 \\ http://www.nber.org/papers/w11023
}

\author{
NATIONAL BUREAU OF ECONOMIC RESEARCH \\ 1050 Massachusetts Avenue \\ Cambridge, MA 02138 \\ January 2005
}

Levine: University of Minnesota and the NBER (rlevine@ csom.umn.edu). Schmukler: World Bank, visiting the IMF Research Department during 2004-2005 (sschmukler@worldbank.org). We are indeed grateful to Juan Carlos Gozzi Valdez for truly outstanding research assistance and for giving us very useful suggestions. We are also grateful to Tatiana Didier, who also helped us at the initial stages of the paper. For helpful comments, we thank seminar participants at the University of Minnesota, Paul Povel, Raj Singh, and David Smith. We thank the World Bank Latin American Regional Studies Program and Research Support Budget for ample financial support. The findings, interpretations, and conclusions expressed in this paper are entirely those of the authors and do not necessarily represent the views of the World Bank. The views expressed herein are those of the author(s) and do not necessarily reflect the views of the National Bureau of Economic Research.

(C) 2005 by Ross Levine and Sergio L. Schmukler. All rights reserved. Short sections of text, not to exceed two paragraphs, may be quoted without explicit permission provided that full credit, including (C) notice, is given to the source. 
Internationalization and the Evolution of Corporate Valuation

Ross Levine and Sergio L. Schmukler

NBER Working Paper No. 11023

January 2005

JEL No. G15, F36, F20

\section{$\underline{\text { ABSTRACT }}$}

By documenting the evolution of Tobin's " $q$ " before, during, and after firms internationalize, this paper provides evidence on the bonding, segmentation, and market timing theories of internationalization. Using new data on 9,096 firms across 74 countries over the period 1989-2000, we find that Tobin's "q" does not rise after internationalization, even relative to firms that do not internationalize. Instead, "q" rises significantly one year before internationalization and during the internationalization year. But, then "q" falls sharply in the year after internationalization, relinquishing the increases of the previous two years. To account for these dynamics, we show that market capitalization rises one year before internationalization and remains high, while corporate assets increase during internationalization. The evidence supports models stressing that internationalization facilitates corporate expansion, but challenges models stressing that internationalization produces an enduring effect on "q" by bonding firms to a better corporate governance system.

Ross Levine

Finance Department, Room 3-257

Carlson School of Management

University of Minnesota

321 19th Avenue South

Minneapolis, MN 55455

and NBER

rlevine@csom.umn.edu

Sergio L. Schmukler

Development Research Group

World Bank

Washington, DC 20433

sschmukler@worldbank.org 


\section{Introduction}

A substantial literature examines the impact of international financial integration on aggregate economic performance, such as economic growth, investment, the cost of capital, and financial development (Bekaert and Harvey, 2000; Bekaert, Harvey, and Lundblad, 2001, 2004; Chari and Henry, 2002, 2004; Henry, 2000a,b, 2003; and Levine and Zervos, 1998a,b). ${ }^{1}$ Research typically finds that integration has positive implications at the country level. To further dissect the causes and consequences of international financial integration, an emerging body of work exploits cross-firm variation in integration. In particular, researchers compare firms that access international financial markets with firms from the same country that do not internationalize (e.g., Doidge, Karolyi, and Stulz, 2004 and Pagano, Roell, and Zechner, 2002). ${ }^{2}$

At the firm level, some researchers argue that corporations "internationalize" - by crosslisting, issuing depositary receipts, or raising capital in major financial centers - in order to bond themselves to a better corporate governance framework. Theories of the firm explain that corporate insiders (managers and larger shareholders) may exploit their positions of control for private gain, with adverse ramifications on the firm and small shareholders. ${ }^{3}$ The ability of small shareholders to mitigate this agency problem depends on a multitude of factors, including the laws and enforcement mechanisms governing minority shareholder rights. Consistent with this prediction, La Porta et al. (2002) find that firms in countries with better investor protection laws have higher Tobin's $q$ than comparable firms in countries with weaker governance systems. Put succinctly, investors pay more for firms that face stronger investor protection laws. Extending

\footnotetext{
${ }^{1}$ Bekaert and Harvey (2003), Edison et al. (2002), and Karolyi and Stulz (2003) provide very helpful reviews of the literature.

${ }^{2}$ Also see Claessens, Klingebiel, and Schmukler (2003), Lang, Lins, and Miller (2003), Lang, Raedy, and Yetman (2003), Levine and Schmukler (2003), Patro and Wald (2004), and Schmukler and Vesperoni (2003), among many others.

${ }^{3}$ See, for instance, Coase (1937), Hart (1995), and Jensen and Meckling (1976).
} 
this to internationalization, the bonding view argues that by listing in markets with stronger investor protection mechanisms, firm insiders "bond" themselves to a better corporate governance system with positive ramifications on $q .{ }^{4}$ Thus, the bonding - agency cost - view of internationalization makes both a cross-section and a time-series prediction regarding corporate valuation. By internationalizing in major financial centers with stronger investor protection laws, (i) markets will value these firms more highly than purely domestic firms, and (ii) these firms will experience an increase in $q$ after internationalizing. Thus, a natural way to assess the bonding view is to trace the time-series pattern of the Tobin's $q$ of firms that internationalize and compare this to the pattern of $q$ s of firms that do not internationalize.

This paper documents the evolution of Tobin's $q$ and its components before, during, and after firms internationalize and thereby provides evidence on the bonding view - as well as other theories of internationalization that we describe below. We study the valuation of "international firms" over time and compare it with that of "domestic firms" (firms that do not internationalize). Doidge, Karolyi, and Stulz (2004) examine a cross-section of firms and find that firms cross-listed in the U.S. have higher Tobin's $q$ than non-cross-listed firms. Since theories of internationalization provide predictions about the time-series patterns of $q$ and its components, we trace the evolution of $q$, market capitalization, corporate assets, and debt during the process of internationalization. Furthermore, endogeneity concerns are particularly acute when examining $q$ in a pure cross-section because highly valued firms may choose to internationalize more frequently than low-valued ones. Adding the time-series dimension to cross-firm comparisons of international integration provides valuable information on whether and how internationalization influences $q$.

\footnotetext{
${ }^{4}$ See Benos and Weisbach (2004), Coffee (1999, 2002), and Stulz (1999). On disclosure standards, see Biddle and Suadagaran (1992), Fuerst (1998), and Huddart, Hughes, and Brunnermeier (1999).
} 
To document the evolution of $q$ - and its components - during the process of internationalization, we construct a new database. The data cover up to 9,096 firms across 74 countries over the period 1989 to 2000. The data include information on firms that internationalize as well as a control group of firms that do not cross-list, issue depositary receipts, nor raise capital abroad. Besides adding the time-series dimension, our sample is broader than past work. Most papers focus only on the U.S. market, while we consider equity capital raisings in all international markets. Although the focus is on $q$, we also examine the evolution of each of the components of $q$ to describe the internationalization process more fully.

The major findings are as follows. First, on average, firms that internationalize at some point in our sample have higher $q$ s than firms that never internationalize, but this difference exists years before firms actually access international equity markets. Second, when examining firms before and after they internationalize, we find that (a) $q \mathrm{~s}$ are not higher after internationalization and (b) the $q$ of firms that internationalize does not increase relative to that of domestic firms after internationalization. Third, when tracing out the dynamics in more detail, we find that $q$ rises significantly one year before internationalization and then falls sharply in the year after internationalization. Indeed, only one year after internationalization, the temporary jump in $q$ vanishes (at the five percent significance level). Fourth, in terms of the components of $q$, market capitalization rises one year before internationalization and remains high thereafter, while corporate assets increase during internationalization as corporations expand (consistent with Pagano, Roell, and Zechner, 2002). Thus, firms that internationalize grow relative to firms that do not internationalize, but they do not enjoy higher $q$ values after internationalization.

These findings hold after controlling for several factors and after conducting an array of sensitivity checks. In evaluating corporate valuation, we control for firm-specific factors, 
worldwide changes in industry-specific valuations, and national economic performance. Specifically, we control for the sales growth of each firm, the average Tobin's $q$ (computed globally) of each firm's industry, and national economic growth in each country. Furthermore, we use country and year dummy variables. We also sub-divide and confirm the analysis along a number of dimensions. In particular, we consider separately (i) over-the-counter (OTC) and private placements, (ii) exchange listings, (iii) internationalization that involves raising capital, (iv) internationalization activity that does not involve raising capital, (v) private capital raisings, (vi) public capital raisings, (vii) only U.S. listings, and (viii) Level III American Depositary Receipts (ADRs) in the U.S. For each of these separate samples, we confirm the results. In additional sensitivity analyses, we condition on an array of country specific information, such as stock market liquidity, the legal protection of shareholder rights, international differences in accounting standards, judicial efficiency, and legal heritage. We also assess the robustness by controlling for price-earnings ratios, stock returns in the U.S., and equity returns in each firm's home market. The conclusions remain unaltered.

Our findings directly relate to three strands of the literature. First, this paper adds to the growing empirical debate about the agency cost - bonding - view of internationalization. Besides the work by Doidge, Karoyli, and Stulz (2004) described above, Doidge (2004) finds that cross-listed firms have lower voting premia, which is consistent with the bonding hypothesis. Reese and Weisbach (2002) also argue that firms from high shareholder protection countries list in the U.S. to raise capital, while those from weak shareholder protection countries list in the U.S. to bind themselves to better corporate governance mechanisms. Others disagree. Licht (2003, 2004) and Pinegar and Ravichandran (2003) argue that internationalization does not 
effectively bond firms to improved governance standards. ${ }^{5}$ Siegel (2004) finds that cross-listing in the U.S. did not deter Mexican firm insiders from expropriating corporate resources. In this paper, we find no evidence that internationalization produces an enduring effect on $q$, and no evidence that the $q$ of international firms increases after internationalization relative to that of domestic firms. This poses a challenge to models that predict that bonding to a better corporate governance system increases $q$ in the long run.

Second, our findings are consistent with segmentation theories of internationalization. When frictions, such as regulations, informational asymmetries, and transaction costs, impede investors from holding internationally diversified portfolios, firms from segmented markets may face a higher cost of capital because international investors are unable to purchase their shares as part of an internationally diversified portfolio. By internationalizing, firms from segmented markets may become part of the portfolios of international investors and thereby lower their cost of capital. ${ }^{6}$ Also, internationalization may help firms access more liquid foreign markets. If a firm's shares are more liquid, this makes them more attractive to buyers with positive ramifications on share prices. ${ }^{7}$ Internationalization can also make it easier for analysts and potential investors to acquire information about firms, which may attract new investors, boost demand for shares, and lower funding costs (Merton, 1987). ${ }^{8}$ Thus, these segmentation theories

\footnotetext{
${ }^{5}$ Also, Bauer, Clark, and Wójcik (2004) find that European firms that cross-list in the U.S. have higher corporate governance standards even before cross-listing. This is consistent with, among others, the view that only companies with high corporate governance standards are able to access international markets.

${ }^{6}$ Building on international asset pricing models by Black (1974), Solnik (1974), and Stulz (1981), Alexander, Eun, and Janakiramanan (1987), Errunza and Losq (1985), and Stapleton and Subrahmanyam (1977) develop models of the impact of internationalization on stock returns.

${ }^{7}$ See, for example, Amihud and Mendelson (1986) and Brennan and Subrahmanyam (1996). Chowdhry and Nanda (1991), Madhavan (1995), and Pagano (1989) suggest that multi-market liquidity effects of internationalization are ambiguous. Empirically, cross-listing in the U.S. market tends to lower bid-ask spreads and increase trading activity (see, for example, Domowitz, Glen, and Madhavan, 1998; Foerster and Karolyi, 1998; Smith and Sofianos, 1997; and Werner and Kleidon, 1996).

${ }^{8}$ On information asymmetries as a motive for cross-listings, see models by Cantale (1996), Fuerst (1998), and Moel (2000). On analysts, Baker, Nosfinger, and Weaver (2002) find that analyst coverage increases after cross-listing, suggesting that internationalization increases information flow. Ahearne, Griever, and Warnock (2004) and Ammer
} 
predict that integration lowers firms' cost of capital. But, these segmentation theories do not predict that internationalization has lasting effects on $q$. Chari and Henry (2002) argue that by accessing cheaper capital, firms expand their assets so that there is no long-term effect from integration on $q .{ }^{9} \quad$ Consistent with this work, we find that firms expand after they internationalize, but $q$ is not higher after internationalization.

Third, this paper's findings are connected to recent research on market timing. Firms may decide to list abroad to exploit a temporarily "hot" market. Consistent with this hypothesis, Henderson, Jegadeesh, and Weisbach (2004) find that firms raise capital in the U.S. and U.K. in "boom" markets, before returns fall. Others, however, do not find consistent evidence of postlisting underperformance by capital raising foreign firms, as the market timing hypothesis predicts. ${ }^{10}$ Consistent with the market timing hypothesis, we find that $q$ rises before internationalization and then falls immediately afterwards. However, even after controlling for a number of factors that are designed to measure market sentiment (e.g., price-earnings ratios, U.S. stock returns, local stock returns, the global industry $q$ of each firm, and capital flows), we reproduce the same time-series pattern of $q$ described above. This suggests that market timing is not the only force underlying the results.

et al. (2004) show that firms that cross-list in the U.S. reduce the information costs for U.S. investors. Moreover, several papers find that familiarity, as proxied by trade, common language, colonial ties, etc., influence investment decisions, including cross-listing decisions (Grinblatt and Keloharju, 2001; Huberman, 2001; Kang and Stulz, 1997; Pagano et al., 2001; and Sarkissian and Schill, 2004). There are countervailing views, however. Sarkissian and Schill (2003) find that firms from markets with the highest pre-cross-listing return correlations achieve the greatest cost of capital reduction, which is inconsistent with some market segmentation theories.

9 Empirically, research finds that internationalization is accompanied by positive abnormal returns and then abnormal returns turn negative or disappear after integration. See, Alexander, Eun, and Janakiramanan (1988), Errunza and Losq (1985), Jayaraman, Shastri, and Tandon (1993), Lau, Diltz, and Apilado (1994), and Miller (1999).

${ }^{10}$ See Errunza and Miller (2000) and Foerster and Karolyi (1999, 2000). 
The remainder of the paper is organized as follows. Section II discusses the data. Section III presents the basic results. Section IV presents several additional robustness tests. We conclude and discuss the implications of our results in Section VI.

\section{Data}

To analyze the evolution of corporate valuations before, during, and after firms access international equity markets we need (i) data on the international activity of firms, including dates of equity capital raisings in international markets, cross-listings, and depositary receipts issuances, (ii) firm-level data on a range of firm attributes, both for international and domestic firms, and (iii) country-specific data on macroeconomic, institutional, and financial conditions.

One contribution of this paper is that we collect more data on the international equity market activity of firms than past studies. Most papers focus only on the ADR market, and exclude international financial markets beyond the U.S. We consider a much broader array of international equity markets.

The data for identifying and dating each firm's international activities come from the following sources.

First, besides the Bank of New York's standard database (the Complete Depositary Receipt Directory) that contains information on current depositary receipt activities, the Bank of New York gave us access to their historical databases and reports on (i) depositary receipt program initiation dates, (ii) termination dates (if any), (iii) capital raisings, and (iv) trading activity. These data form a comprehensive database on American and Global depositary receipt programs. The historical data start in January 1956, but for the vast majority of programs, the data begin after 1980 . 
Second, Euromoney provides the dates when firms raise equity capital in international markets, including cross-listings and issuance of Global Depositary Receipts (GDRs). Thus, the Euromoney data substantively enhance the identification of international firms. The Euromoney database covers 8,795 cross-border equity issuances and cross-listing operations from 5,665 firms in 86 countries over the period January 1983 - April 2001.

Finally, information on dating the initiation of international equity market activities was augmented with data from the London Stock Exchange (LSE), NASDAQ, and New York Stock Exchange (NYSE) on listing dates by foreign corporations.

Consistent with our objective of assembling a broad database on internationalization, we classify firms as international if they (i) issue depositary receipts, (ii) cross-list, or (iii) raise equity capital through private or public placements abroad. Our definition is thus more general than listing in an international exchange alone, as we also include capital raisings without listing. As presented below, we examine different sub-samples of international firms to assess whether the evolution of Tobin's $q$ differs for different methods of internationalization.

Besides determining whether a firm is international or not, we collect information on firm characteristics, including balance sheet and income statement variables and data on market capitalization, from several sources, including the Worldscope database (Thomson Financial Company), Standard \& Poor's Emerging Markets Data Base (EMDB), and Bloomberg.

To measure firm valuation we use Tobin's $q$. Given data availability, we calculate it as the market value of equity plus the book value of debt (computed as book value of assets minus the book value of equity) divided by the book value of assets. Our estimate of Tobin's $q$ does not use the market value of debt in the numerator and does not attempt to use the replacement cost of assets in the denominator. It is difficult to avoid these simplifications in a database that 
covers over 9,000 firms from 74 countries. ${ }^{11}$ Similar definitions of Tobin's $q$ have been widely used in the literature (see, for example, Chari and Henry, 2002; Claesssens and Laeven, 2003; Doidge, Karolyi, and Stulz, 2004; Klapper and Love, 2004; La Porta et al., 2002; and Shin and Stulz, 2000).

Worldscope provides firm-level data using local GAAP (Generally Accepted Accounting Principles). Although attempts are made to make data consistent across countries, these efforts have limitations. Differences in accounting standards across countries could increase Tobin's $q$ in some countries relative to others. To address concerns regarding possible biases introduced by cross-country differences in accounting practices, we conduct two procedures. First, we include country fixed effects in our regressions. Second, we use the relative $q$ of international firms (defined as the $q$ of each international firm divided by the average $q$ of all domestic firms in the firm's home country) as dependent variable in some specifications. Relative $q$ focuses on within country variation in corporate valuations and is unaffected by national differences in accounting practices. ${ }^{12}$

After removing financial firms, outliers, firms with missing values of $q$, and firms with less than three observations, we are left with a sample of 9,096 firms from 74 countries covering the period 1989 to 2000, totaling 66,963 firm-year observations. Appendix Table 1 lists the 74

\footnotetext{
${ }^{11}$ We did not attempt to calculate the replacement cost of assets in the denominator since the required data are generally not available for our sample of firms and countries have different ways for accounting for depreciation of physical assets. In addition, we did not want to impose a fixed depreciation formula, since the age of assets varies by economy. We also did not attempt to calculate the market value of debt, as this would require us to use data on corporate bond rates (see Blanchard, Rhee, and Summers 1993), which are not available for most countries in our sample. Rather than making further assumptions, we follow the alternative convention of using the book value of debt as a proxy for its market value and the book value of assets as a proxy for their replacement cost.

${ }^{12}$ A potential concern regarding our measure of Tobin's $q$ is related to the impact of inflation. In inflationary economies, the use of book values could bias our estimates of $q$ upwards as we might underestimate the numerator, specially when assets are reported using historical costs. In order to address this concern, we estimated regressions including inflation as a control variable, but this did not alter the results. Also, by using the relative $q$ as a dependent variable we avoid problems with inflation, since the $q$ of all firms within the same country is affected in a similar way by inflation.
} 
countries covered in the study and the number of domestic and international firms per country, as well as the period analyzed for each country and summary statistics of Tobin's $q .{ }^{13}$

As controls we include firm-specific variables commonly used in studies of firm value. Specifically, we use the average sales growth over the last two years as a proxy for firms' growth prospects. We use sales rather than earnings in order to avoid the problems generated by the volatility and manipulability of earnings. We also control for industry-level effects by including the average Tobin's $q$ of the global industry to which a firm belongs as an independent variable.

Finally, we also collect country-level information. In the basic specifications we control for real GDP growth, which comes form the World Bank World Development Indicators. In robustness tests discussed in more detail in Section IV, we control for additional country-level factors, which might affect not only firms' valuations but also their willingness and ability to access international equity markets, including a country's institutional quality, shareholder rights, and legal origin. We also use some indicators of stock market development as independent variables, such as market capitalization over GDP and turnover (value traded over market capitalization), and an index of accounting standards.

\footnotetext{
${ }^{13}$ Some countries do not have any international firms. We keep these in the sample as a control group, but emphasize that this paper's results hold when we exclude countries with zero or only one international firm. Also, Japanese firms represent about 30 percent of the total firms in our sample. We therefore re-did our analyses excluding Japanese firms and this yields the same conclusions reported below.
} 


\section{Results}

This section provides empirical evidence on the evolution of Tobin's $q$ as firms internationalize. We proceed as follows. The first subsection tests (i) whether international firms have higher $q$ s than domestic firms and (ii) whether there is a significant increase in $q$ after firms internationalize. The second subsection looks at various sub-samples to provide robustness tests and additional information on the bonding, segmentation, and market timing theories of internationalization. In particular, we examine the exact mechanisms and exchanges through which firms internationalize and whether they raise new equity capital. In the analyses we also compare firms that internationalize with domestic firms (firms that do not internationalize) to assess whether there is a relation between internationalization and valuation that holds when conditioning on changes in each firm's home market. The third subsection traces out the yearby-year evolution of $q$ and its components before, during, and after internationalization. This provides a finer characterization of the internationalization process.

\section{A. Before and After Internationalization}

\section{Preliminary Evidence: Do International Firms Have Higher Qs?}

As a preliminary step, the top panel of Figure 1 compares the average $q$ of international firms with the average $q$ of domestic firms. Domestic firms are firms that never issue depositary receipts, raise capital in international markets, or cross-list on the LSE, NASDAQ, or NYSE. Thus, we compute the average $q$ across all domestic firms, across all years in the sample, which includes 57,876 firm-year observations. International firms are firms that at some point in the sample period "internationalize." Thus, we characterize a firm as international even if it has not yet issued a depositary receipt, raised capital abroad, or cross-listed in an international market. 
Given this definition, we compute the average $q$ across all international firms, across all years. This includes 9,087 firm-year observations. Below, we explicitly assess what happens to international firms' $q$ before and after internationalization.

As shown in Figure 1, international firms' $q$ averages 1.55, while domestic firms have an average $q$ value of 1.39. The difference is statistically significant at the one percent level. The difference of 0.16 is over ten percent of the sample mean of 1.41 and is 18 percent of the standard deviation of Tobin's $q$ across all the firms in the sample (0.86). While international firms have higher $q$ s on average, this does not necessarily imply that the $q$ s of international firms increase after they internationalize. Firms that internationalize may be more highly valued than domestic firms even before they internationalize, as discussed below.

To assess whether the Tobin's $q$ of international firms is higher than the $q$ of domestic firms conditional on firm, industry, and country characteristics, Table 1 presents a series of regressions. The first six regressions include all firms in the sample, which involves up to 66,963 firm-year observations. The next three regressions restrict the sample to firms with more than 100 million U.S. dollars in average assets, where the average is taken for each firm over the sample period. We examine this subset of firms because both market valuation and access to international markets may be different for very small firms and excluding very small firms may improve the comparability of firms across countries.

The simplest specification regresses Tobin's $q$ for firm $\mathrm{f}$, from country c, in year $\mathrm{t}\left(q_{\mathrm{c}, \mathrm{f}, \mathrm{t}}\right)$ on the internationalization dummy $\mathrm{c}_{\mathrm{c}, \mathrm{f}, \mathrm{t}}$, which is a dummy variable for firm $\mathrm{f}$, from country $\mathrm{c}$, during year t. This dummy variable equals one on and after the year when the firm becomes international and zero before the firm internationalizes; it is also equal to zero for domestic firms. All the regressions include country and year dummy variables. Furthermore, in some 
specifications, we control for (i) the national rate of economic growth of each firm's home country since macroeconomic success may simultaneously influence valuation and access to international markets, (ii) the growth rate of sales over the last two years since firm growth opportunities may shape both the market's assessment of future cash flows and the benefits of internationalizing, and (iii) the global industry $q$ (averaged across all firms in the industry) of each firm's industry since industry developments may simultaneously drive domestic market valuations and international demand for the firm. ${ }^{14}$ We include these variables to control for firm, industry, and country-specific factors that may influence both valuation and access to international markets.

As shown in Table 1's regressions 1, 2, and 7, the internationalization dummy enters positively and significantly. Thus, when we simply examine the valuation of firms after they internationalize and compare this to firms that have not internationalized (at least yet), international firms have higher valuations. This result holds for firms of different sizes and when controlling for country, firm, and industry factors. While these findings confirm that international firms have higher $q$ s than domestic firms, they do not necessarily imply that this difference is generated by the internationalization process per se.

\section{Is $Q$ Higher After Internationalization?}

Next, we examine whether $q$ rises after firms become international. As a preliminary step, the bottom panel of Figure 1 compares the average $q$ of international firms before and after internationalization. As the figure shows, the $q$ of international firms does not increase after they internationalize. In fact, the average $q$ is lower after internationalization.

\footnotetext{
${ }^{14}$ We take the natural logarithm of one plus the growth rate of each country's Gross Domestic Product, i.e., $\log$ of (1 + GDP growth), and the natural logarithm of one plus each firm's average sales growth over the last two years, i.e., $\log$ of $(1+$ two-year average sales growth). We take logs to control for outlier observations, but this does not affect the results.
} 
While Figure 1 displays unconditional means, Table 1 provides formal tests of whether $q$ increases following internationalization, conditional on country, industry, and firm characteristics. As a first step in making this assessment, we include both the internationalization dummy and a dummy variable (international dummy $y_{\mathrm{c}, \mathrm{f}, \mathrm{t}}$ ) that equals one for all years if firm $\mathrm{f}$ from country $\mathrm{c}$ internationalizes at some point in the sample, and equals zero if it is a domestic firm for the entire sample period. By including the international dummy along with the internationalization dummy, we test whether $q$ rises after internationalization and/or whether firms that internationalize at some point tend to have higher $q$ s on average.

We find no evidence that $q$ rises after internationalization. In Table 1's regressions 3, 4, and 8 , including the international dummy eliminates the significance of the internationalization dummy. This provides suggestive evidence that it is not the act of internationalizing per se that is associated with higher valuation. Rather, these regressions imply that the big difference is between firms that internationalize at some point and firms that do not, consistent with the idea that better firms are the ones that are able to access international markets.

Finally in Table 1, we provide a more direct test of firm values before and after internationalization. We simultaneously include the internationalization dummy and a dummy variable that equals one before a firm becomes international and zero otherwise (before internationalization dummy $y_{c, f, t}$ ). For domestic firms (firms that never internationalize), the before internationalization dummy equals zero throughout. If $q$ rises after internationalization, then the estimated coefficient on the internationalization dummy variable should be significantly larger than the coefficient on the before internationalization dummy variable. We find the opposite. In Table 1's regressions 5, 6, and 9, the before internationalization dummy variable enters with a larger coefficient than the internationalization dummy. Although there is not a 
statistically significant difference, as reported at the bottom of the table, the results clearly demonstrate that corporate $q$ s do not rise after firms internationalize. In sum, the results in Table 1 suggest that firms that internationalize at some point in the sample tend to have higher $q$ s than domestic firms, but $q$ does not rise after internationalization.

\section{B. Internationalization: Different Sub-Samples}

To further assess whether $q$ rises after internationalization, we cut the data into a variety of sub-samples and re-do the analysis. Our sub-sample selection is primarily motivated by arguments made by the bonding literature. According to this literature, internationalization procedures that involve greater information disclosure and adherence to stricter investor protection laws will have a bigger impact than procedures that do not boost information disclosure and investor protection standards. Thus, pooling all types of internationalization together could potentially bias downward the bonding effect of internationalization. Here, we test whether the results hold when differentiating firms by (i) whether they list in a major public exchange or not when internationalizing, (ii) whether they raise new equity capital or not when they internationalize, (iii) whether firms raising capital in international markets do so through private placements or public offerings, and (iv) whether firms internationalize into U.S. markets through Level III ADRs or through different arrangements. ${ }^{15}$ Note that many of these categorizations overlap. In Tables 2-5, we only include firms with more than 100 million U.S.

\footnotetext{
${ }^{15}$ Some firms may have several types of listings or equity offerings in international markets. For example, a firm might first raise capital in international markets through a private placement and then cross-list in a public exchange. In Tables 2-5 we classify firms according to their first activity in international markets. So, if a firm privately raises capital abroad and then lists on a major international exchange, we use the date of the private capital raising as the year of internationalization and include the firm in the private capital raising sample.
} 
dollars in average assets, which is most directly comparable to the sample of firms in regressions 7-9 of Table $1 .^{16}$

\section{Differentiating by Exchange Type}

Table 2 presents regression specifications similar to those in Table 1. Table 2's regressions 1-3 use a sub-sample of firms that internationalize via the U.S. OTC market and private placements in international markets, while regressions $4-6$ use a sub-sample of firms that cross-listed or raised equity capital in a major public exchange. ${ }^{17}$

Besides assessing the robustness of the earlier results, we separately consider (i) OTC/private placements and (ii) exchange listings because exchange listings typically require more information disclosure and adherence to tighter corporate governance standards. Thus, from the perspective of the bonding hypothesis, we might expect to find that internationalization induces an enduring increase in $q$ for exchange listed firms but not for OTC/private placements due to the enhanced governance environment.

The Table 2 results on the sample of OTC/private placements and the sample of exchange listings are the same as the full sample findings discussed above: international firms have higher $q$ s than domestic firms, but their valuations do not rise after internationalization. These findings do not support arguments that internationalizing into major public exchanges (with arguably better governance mechanisms) has a different impact on firms' valuation than using the OTC market or private placements. More specifically, regressions 1 and 4 show that $q$ is not higher after internationalization. These regressions include both domestic firms and firms that internationalize, where the domestic firms form a control group that allows us to assess whether

\footnotetext{
${ }^{16}$ We also estimated the regressions in Tables 2-5 including all the firms and obtained similar results.

${ }^{17} \mathrm{We}$ also estimated regressions for firms that internationalize via the U.S. OTC market and private placements in international markets separately and obtained similar results.
} 
the $q$ of firms that internationalize rises relative to the valuations of domestic firms. ${ }^{18}$ For the OTC/private placements sample (regression 1) and the exchange listings sample (regression 4), the internationalization dummy does not enter with a coefficient that is significantly larger than the coefficient on the before internationalization dummy. In regressions 2, 3, 5, and 6, we only include firms that internationalize at some point in the sample. As shown, $q$ is not larger after internationalization when examining either the OTC/private placements sample (regression 2) or the exchange listings sample (regression 5). ${ }^{19}$

In Table 2, we also examine relative Tobin's $q$, which equals an international firm's $q$ divided by the average $q$ of domestic firms from the same country in the same year. Thus, relative Tobin's $q$ is a direct measure of international firm valuation relative to average domestic firm valuation. The bonding hypothesis predicts that a firm that internationalizes into a foreign market with better corporate governance mechanisms will experience a rise in $q$ relative to domestic firms that do not internationalize (and thus do not commit to a higher level of shareholder protection).

The results indicate that relative $q$ does not increase after internationalization. The internationalization dummy does not enter significantly in either the OTC/private placements sample (regression 3) or the exchange listings sample (regression 6). Again, it does not matter whether we focus on a sample of firms that lists on major public exchanges or internationalizes through the OTC market or private placements. The finding that relative $q$ does not rise after

\footnotetext{
${ }^{18}$ Regressions 1 and 4 include all domestic firms and only the international firms being considered in each case (those with OTC/private offerings in regression 1 and those listed in major public exchanges in regression 4). Since both of these regressions include domestic firms, the total number of observations in these regressions sum to more than total observations of regression 7 of Table 1.

${ }^{19}$ In terms of matching observations between Tables 1 and 2, note that Table 2 only includes firms with more than 100 million U.S. dollars in average assets. In Table 2, there are 3,521 observations of OTC/private placements and 3,351 observations of exchange listed international firms. Thus, the total number of international firm observations is 6,872. There are also 32,251 domestic firm observations. Thus, we have a total number of observations of 39,123 , which equals the total numbers of observations in columns 7-9 of Table 1 . The same demarcations hold in Tables 3-5.
} 
firms cross-list in major exchanges where shareholder protection and information disclosure regulations are more effective does not offer support for the bonding hypothesis.

\section{Differentiating by Equity Offering Type}

Next, we differentiate firms by whether they raise capital when they internationalize. Table 3 presents the same regressions as Table 2 except that the first three regressions use a subsample of international firms that raise new equity capital when they internationalize. The next three regressions, 4-6, use a sub-sample that consists of international firms that do not raise new equity capital when they internationalize. In particular, international firms are classified as "capital raising" if they raised new equity through a public or a private offering in international markets. ${ }^{20}$ Level III ADRs involve capital raisings in public U.S. exchanges so these primary market activities are part of the capital raising sample. Similarly, the capital raising sample includes GDRs that involve new equity issuance, direct listings that entail capital raising in the U.S. and other financial centers, and private placements, such as Regulation 144A offerings in the U.S. and private placements in other international markets.

We again find that $q$ does not rise after internationalization for either the sample of firms that raise capital, or the sample that does not (Table 3). Since the patterns replicate all of our earlier findings, we keep the discussion very brief. As shown, (i) international firms have higher $q$ s than domestic firms and (ii) neither $q$ nor relative $q$ increase after internationalization. Besides confirming the results presented above, the Table 3 regressions indicate that the pattern for capital raising and non-capital raising firms is similar.

\footnotetext{
${ }^{20}$ Firms are only classified as capital raising if they issue new equity abroad. That is, firms are not classified as capital raising if they raise new equity capital in their home market but do not also raise new equity abroad. All of the international capital raisings in our sample take place in developed markets (e.g., Frankfurt, Hong Kong, London, Luxembourg, New York, and Zurich).
} 


\section{Differentiating by Capital Raising Type}

Next, we focus only on the sample of firms that raise new equity capital when they internationalize, but we divide these into two groups: private capital raisings and public capital raisings. Thus, some firms raise capital when they list on major public exchanges, such as the

LSE, NASDAQ, and NYSE. Other firms raise capital through private placements in international markets that do not involve an exchange listing. We examine each of these groups separately in Table 4 to assess whether the combination of capital raising and listing on a major exchange produces different results. Specifically, raising new equity and listing on a major exchange may provide stronger bonding to an improved governance regime than either one separately, so that this smaller sample of firms might experience an increase in $q$ after internationalization.

Table 4 indicates that $q$ does not rise after internationalization, even for firms that simultaneously raise capital and list on major exchanges. It is possible to see exactly the same pattern for private and public capital raisings, and this pattern is the same as that reported above for the full sample and other sub-samples. In particular, while firms that internationalize tend to have on average higher $q$ s than domestic firms (regressions 1 and 4), $q$ does not rise after internationalization.

\section{Differentiating by Listing in U.S Markets}

Finally, we only examine internationalization into the U.S. market. There may be concerns that examining the full sample of international venues produces lots of noise and makes it difficult to isolate the relationship between internationalization and valuation. Furthermore, focusing on the U.S. is important if one believes that the U.S. market provides a particularly effective shareholder protection environment. If this is true, then focusing on the U.S. provides a 
more powerful test of whether firms that internationalize into stronger shareholder protection regimes enjoy a boost in valuation afterwards.

Table 5 presents regressions on two samples of firms that internationalize into U.S. markets. The first sample includes all types of U.S. listings (regressions 1-3). This includes all ADR programs, firms that raise equity capital in U.S. markets (including through Regulation 144A private placements), and cross-listings on the NASDAQ and NYSE. The second sample only includes Level III ADRs, which are ADRs listed on a U.S. exchange that involve a capital raising component (regressions 4-6). ${ }^{21}$ These ADR programs are subject to more strict disclosure requirements and liability standards. In particular, they require full SEC disclosure with Form 20-F, reconciliation of financial statements to U.S. GAAP (Generally Accepted Accounting Principles), and compliance with the exchange's listing rules and corporate governance standards. ${ }^{22}$ Issuers are also subject to the strict liability provisions of Section 11 of the Securities Act of 1933, which implies that they face direct liability for any material misleading statement or omission. $^{23}$ Level III ADRs offer better investor protection than other forms of internationalization and therefore, from the perspective of the bonding hypothesis, we should expect to find that this type of listings induces an enduring increase in $q$, at least relative to domestic firms that do not improve their corporate governance practices through internationalization.

21 We also estimated the regressions for different sub-samples (Level I and II ADRs and Regulation 144A placements), obtaining similar results.

${ }^{22}$ Form $20-\mathrm{F}$ is used by foreign firms to file annual reports with the SEC (equivalent to Form 10-K for U.S. issuers). There are two sets of financial statement requirements, referred to as Item 17 ("low disclosure") and Item 18 ("high disclosure"). Level III ADRs issuers are required to file an Item 18 Form 20-F, which requires disclosures on income taxes, leases, pensions, non-consolidated affiliated, related parties, and industry and geographic segment information.

${ }^{23}$ Firms with Level I and II ADRs and Regulation 144A placements are subject to liability under Section 10(b) and Rule 10b-5 of the Exchange Act. Liability under these provisions requires the plaintiff to proof that the defendant acted with an intent to defraud ("scienter"). Therefore, firms with Level III ADRs are subject to stricter liability standards (see Greene et al., 2000). 
Table 5 indicates that the valuation patterns for U.S. listings do not differ from the results presented above: $q$ does not rise significantly after internationalization. These results hold for the full sample of U.S. listings (regressions 1-3) and for the much small sample of Level III ADRs (regressions 4-6).

In sum, Tables 1-5 show that (i) international firms on average enjoy higher valuations than domestic firms, (ii) international firm valuations are not significantly higher after they internationalize than they were before, and (iii) the valuation of international firms does not increase relative to that of domestic firms following internationalization. Thus, contrary to some versions of the bonding hypothesis, the evidence on $q$ is inconsistent with the prediction that firms increase their valuation by bonding to a better corporate governance regime through internationalization and that this produces an enduring increase in $q$ relative to firms from the same country that do not internationalize. We now examine the times-series pattern of valuation changes during the process of internationalization in more depth.

\section{Internationalization: Dynamics}

To shed additional light on the bonding, segmentation, and market timing theories of internationalization, this section provides more details on the evolution of $q$ and its components during the process of internationalization. Rather than simply examining corporate valuation before and after firms internationalize, we trace through the year-by-year evolution of $q$ and its components before, during, and after internationalization. We first describe the results and then link these analyses to the different theories of internationalization. 


\section{Results on the Evolution of $Q$ and its Components}

As a preliminary step, Figure 2 plots the evolution of $q$ during the internationalization process. The top panel shows the average $q$ in each year around the internationalization date. It shows that $q$ tends to increase before internationalization, reaching its maximum level during the internationalization year, and then falls. The bottom panel documents a similar pattern for relative $q$. The valuation of international firms increases before internationalization relative to that of domestic firms and then falls after internationalization. The internationalization process seems to have only a temporary impact on firm valuation and does not generate a permanent increase in the $q$ of international firms relative to that of domestic firms.

While Figure 2 displays unconditional means, in Table 6 we use dummy variables to trace trough the year-by-year evolution of $q$ and its components, controlling for other factors. We separately document the time-series patterns of (i) Tobin's $q$, (ii) the numerator of $q$, defined as the market value of equity plus the book value of debt, (iii) the denominator of $q$, which equals the book value of assets of the firm, (iv) the market value of equity, and (v) the book value of debt. Furthermore, we examine each of these five variables relative to domestic firms. As above, we examine each firm's $q$ divided by the average $q$ of domestic firms from the corporation's home market and call this relative Tobin's $q$. Similarly, we examine each firm's market capitalization and divide it by the average market capitalization of domestic firms from the corporation's home market. We do this for each of the components of $q$. Thus, Table 6 contains ten regressions.

Methodologically, we include a series of dummy variables that trace out annual patterns. Thus, for each firm we create a dummy variable called "three years before internationalization dummy" that equals one three years before the firm internationalizes and zero otherwise. 
Similarly, for each firm we create a dummy variable called "two years before internationalization dummy" that equals one two years before the firm internationalizes and zero otherwise. We construct corresponding dummy variables for each of the years surrounding internationalization and the internationalization year itself. Table 6 presents the results.

As shown in Table 6's column 1, one year before a firm internationalizes its $q$ is significantly (at the five percent level) higher than its long-run pre-internationalization value (i.e., its value more than three years before internationalization). Tobin's $q$ rises even further in the internationalization year. However, by the first year after internationalization, $q$ is no longer significantly (at the five percent) higher than its value more than three years before internationalization. While it enters significantly at the ten percent level, there are almost 7,000 observations, what suggests that it is more appropriate to use a five percent significance level. Also, the dummy variable on two years after internationalization does not enter significantly, even at the ten percent level. Furthermore, when looking at the estimated coefficients rather than their significance, one year after internationalization $q$ relinquishes virtually all of its gain during the previous two years. Relative $q$ follows a similar pattern, rising the year before internationalization and even further during the year of internationalization, and then relinquishing these gains during the year after internationalization. Again, the dummy variable for the year after internationalization does not enter with a significant coefficient at the five percent level. The time series pattern is similar to that illustrated in Figure 2. Internationalization does not induce an enduring increase on $q$ relative to the valuation of firms that do not internationalize.

Turning to the components of $q$, the numerator of Tobin's $q$ rises one year before internationalization, rises further in the year of internationalization, and remains high going 
forward. These dynamics are driven primarily by market capitalization, which follows a similar pattern: rising before internationalization, even further during internationalization, and then decreasing but staying at a higher level than before internationalization. The book value of debt does not rise significantly until the year of internationalization. This suggests that markets anticipate internationalization and view it positively, which is reflected in higher prices before firms actually internationalize. This pattern could also reflect market timing, as firms internationalize when their valuation increases.

In contrast, the denominator of Tobin's $q$, total assets, follows a different pattern. Total assets rise significantly when the firm internationalizes, not before. Assets remain higher after internationalization. This is consistent with the view that internationalization coincides with corporate expansion, possibly because of a lower cost of capital and additional capital raisings.

\section{Interpretation and Links to Theory}

Taken together, the evolution of $q$ and its components tell a distinct story that relates to theories of internationalization. Market capitalization rises before the firm internationalizes and then remains high. Assets do not increase before internationalization. Rather, assets rise when the firm internationalizes and then remain higher than they were before internationalization. Thus, $q$ rises before internationalization and even further during the year of internationalization as market capitalization increases. Then, $q$ drops dramatically in the year after internationalization as firms expand.

Note that the differences between international and domestic firms exist and change well before firms internationalize. For example, as shown in regression 2 of Table 6 , the $q$ of international firms relative to that of domestic firms rises before internationalization, not after. As shown in regression 6, the size of international firms relative to domestic firms (measured by 
total assets) rises before they internationalize. Thus, compared to the baseline period of more than three years before internationalization, both the relative $q$ and relative size of firms that internationalize increase years before they actually access international markets. Moreover, while international firms expand relative to domestic firms after internationalization, the $q$ s of international firms relative to that of domestic firms do not rise after internationalization. ${ }^{24}$

The pattern of $q$ and its components presented in Table 6 is consistent with segmentation theories, which predict that internationalization generates a reduction in firms' cost of capital that fosters their expansion. This is what we observe: internationalizing firms expand, both relative to the period before internationalization and relative to domestic firms. Segmentation theories do not predict that $q$ will rise in the long run. Again, this is what we observe: $q$ does not rise after internationalization. We do observe an increase in $q$ before and during internationalization. This is not inconsistent with segmentation theories: if markets anticipate a "good" event internationalization - this will boost stock prices, increasing market capitalization and $q$. Then, with internationalization, profit-maximizing firms respond by raising new capital and expanding, which pushes $q$ back to its trend value. This prediction is validated by the time-series patterns documented in Table 6.

The finding that there is not a permanent increase in the $q$ of international firms relative to that of domestic firms poses a challenge for the view that internationalization bonds firms to a more effective corporate governance system. This view argues that internationalization generates a permanent improvement in corporate governance practices, with a corresponding increase in the $q$ of international firms compared to the $q$ of firms that do not internationalize. While bonding may also lower the cost of capital, encourage firms to expand, and thereby put

\footnotetext{
${ }^{24}$ We constructed versions of Table 6 using the various sub-samples of firms that we use in Tables 2-5 and did not find a permanent increase in $q$ or relative $q$ after internationalization for any of these sub-samples. This confirms the findings from Tables 2-5.
} 
downward pressure on $q$ after internationalization, bonding still implies that international firms commit to a better governance structure than domestic firms. This suggests that the $q$ of international firms relative to that of domestic firms should be higher after internationalization. We do not find this. To be consistent with our findings, bonding models need to account for the very rapid post-internationalization return of $q$ to its baseline value of more than three years before internationalization. We discuss market timing theories of internationalization in the next section, where we extend the analysis to control for market sentiment.

\section{Additional Robustness Tests and Extensions}

Besides the robustness tests discussed throughout the paper, we conducted two additional sets of sensitivity analyses, not shown in the paper, to provide information on the different theories of internationalization.

First, to assess whether market timing fully explains the time-series patterns documented above, we controlled for a wide array of variables that proxy for movements in international stock markets, foreign investor demand, and local market conditions. We control for market conditions because market timing theories suggest that firms issue equity in "hot" markets. Firms might choose to list abroad to take advantage of what they view as a temporarily high price for their shares. Therefore, market timing might explain the temporary rise in $q$ before internationalization.

Thus, we experimented with numerous controls for market conditions. More specifically, our basic specifications (used throughout) indirectly control for worldwide changes in investor sentiment because we include year dummies. Furthermore, our basic specifications control for industry effects by including the global average value of $q$ for each firm's industry. In additional 
robustness tests, we also estimated the regressions including several measures of international stock market performance, including both the annual rate of return and price-earnings ratio of the S\&P 500 index. We also controlled for international investor demand for a country's firms by including portfolio equity flows and total equity flows (the sum of foreign direct investment and portfolio equity flows) into the country, both in U.S. dollars and as a percentage of GDP. We also included variables measuring the degree of internationalization of domestic equity markets, such as the number of international firms over the total number of firms listed in the domestic stock market and the ratio of stock market capitalization of international firms to that of domestic firms. These variables might also proxy for foreign investor interest in local firms. Finally, we included measures of domestic stock market performance, such as local stock index returns and the average $q$ of all firms in the domestic market.

Nevertheless, even after including these proxies for market conditions, we find the same time-series patterns. Although we found some of these control variables to be significant, our results on the evolution of $q$ were not affected by their inclusion. If these variables capture market timing forces, then the robustness of our results to including these controls suggests that market timing is not the only explanation of the times-series pattern of corporate valuation that we identify.

Second, we controlled for shareholder protection laws, accounting standards, and institutional development in the home country. La Porta et al. (2002) find that firms in countries with better investor protection laws have higher Tobin's $q$ than comparable firms in countries with weaker corporate governance systems. We therefore re-did our regressions controlling for the quality of investor protection laws, by including an index of the strength of shareholders 
rights and dummies for a country's legal origin. ${ }^{25}$ Our results are robust to the inclusion of these variables. $^{26}$ We also included some measures of institutional quality, such as an index of the efficiency of the judicial system produced by Business International Corporation and an index of accounting standards produced by the Center for International Financial Analysis and Research, and obtained similar results. The bonding hypothesis predicts that firms from countries with weaker investor protection should experience a larger increase in their valuations after crosslisting than firms from countries with better investor protection. In order to test this hypothesis, we also included interactions between our measures of investor protection and the internationalization dummies in some specifications. These interactions are not significant, and our results were not affected by their inclusion.

\section{Conclusions}

This paper examined the evolution of the corporate valuation of firms that cross-listed, issued depositary receipts, or raised equity capital in international markets over the period 19892000. We documented the time-series patterns of $q$ before, during, and after internationalization and compared these patterns to firms that never internationalized. We also examined the individual components of $q$ in assessing what happens during the process of internationalization.

There are four key findings. First, international firms tend to have higher valuations than domestic firms. More specifically, the average $q$ of firms that at some point in the sample internationalize is higher than the $q$ of firms that never internationalize.

Second, corporations do not experience an enduring increase in $q$ after they internationalize. We find that (a) valuations are not higher after internationalization and (b)

\footnotetext{
25 These are the same variables used by La Porta et al. (2002).

${ }^{26}$ The index of shareholders rights is not significant in most of our regressions while the English legal origin dummy tends to be positive and significant.
} 
valuations of firms that internationalize do not increase relative to those of domestic firms (i.e., the relative $q$ does not increase after internationalization). Thus, although there are large crossfirm differences in $q$, our results are consistent with the view that these differences are not affected by internationalization per se.

Third, in terms of the year-by-year dynamics, $q$ rises before internationalization, but then falls rapidly in the year after internationalization. We find that one year after internationalization the $q$ of international firms is not significantly higher than it was two years (or even three years) before they internationalized. Furthermore, the relative Tobin's $q$ of international firms $(q$ divided by the average $q$ of domestic firms from the same home country) follows the same pattern: rising in the year before internationalization and during the internationalization year, but relinquishing these increases by the year after internationalization.

Finally, in terms of the components of $q$, a firm's market capitalization tends to rise prior to internationalization and remains high thereafter, while the firm's assets increase during internationalization as the firm expands. Thus, firms that internationalize expand relative to domestic firms. On net, however, internationalization is not associated with a lasting effect on valuations as measured by Tobin's $q$.

The results provide new evidence on different theories of internationalization. First, market segmentation theories hold that internationalization boosts firm size but exerts only a fleeting impact on $q$, because overcoming barriers to raising capital abroad does not induce a fundamental improvement in corporate governance. According to market segmentation-type arguments, market values rise because internationalization facilitates, for example, diversification, information flow, or the trading of shares in more liquid markets. The increase in $q$ should be short-lived, however, because corporations expand when the cost of capital falls. 
Consistent with these predictions, we find that internationalization is associated with a permanent increase in market capitalization, a temporary increase in $q$, and a subsequent jump in corporate assets.

Second, the evidence is consistent with market timing arguments. In particular, firms may respond to positive shocks to their share prices by raising capital in international markets. Since the increase in market value before internationalization is also consistent with markets anticipating that the firm is going to enjoy positive future benefits from internationalization (due to a reduction in segmentation, bonding, or any other cause), it is difficult to distinguish market timing from other theories of internationalization. Toward this end, we attempt to control for market timing by conditioning on stock market returns in the U.S. and the domestic market, price-earnings ratios, and global industry $q$ values, among other country, industry, and firm traits. Our results are robust to including these factors. Thus, to the extent that we have appropriately controlled for market timing effects, these findings imply that market timing is at least not the only force underlying the evolution of $q$ and its components.

Third, the results provide evidence regarding the bonding view of internationalization. If internationalization provides a vehicle for firms to adopt a more effective corporate governance regime that reduces the ability of insiders to divert corporate resources for private gain, then this should induce an enduring increase in corporate valuations relative to domestic firms that do not commit to a tougher governance regime through internationalization. However, we find that $q$ and relative $q$ rise prior to internationalization and then fall very quickly back to their long-run pre-internationalization values. Our paper suggests that to be consistent with these time-series patterns, bonding models should explicitly account for the very short-lived increase in $q$ when firms internationalize. 
In the end, our major contribution is that we document the evolution of corporate valuation during the process of internationalization along with the evolution of the components of $q$. We trust that this helps future work (a) distinguish more precisely among different theories of internationalization and (b) develop models that more completely describe international financial integration. 


\section{References}

Ahearne, A., W. Griever, and F. Warnock, 2004. Information Costs and Home Bias: An Analysis of U.S. Holdings of Foreign Equities, Journal of International Economics 62, 313-336.

Alexander, G., C. Eun, and S. Janakiramanan, 1987. Asset Pricing and Dual Listing on Foreign Capital Markets: A Note, Journal of Finance 42, 151-158.

Alexander, G., C. Eun, and S. Janakiramanan, 1988. International Listings and Stock Returns: Some Empirical Evidence, Journal of Financial and Quantitative Analysis 23, 135-151.

Amihud, Y. and H. Mendelson, 1986. Asset Pricing and the Bid-Ask Spread, Journal of Financial Economics 17, 223-249.

Ammer, J., S. B. Holland, D. C. Smith, and F. E. Warnock, 2004. Look at Me Now: The Role of Cross-Listing in Attracting U.S. Shareholders, Board of Governors of the Federal Reserve System, International Finance Discussion Paper No. 815.

Baker, H. K., J. R. Nofsinger, and D. G. Weaver, 2002. International Cross Listing and Visibility, Journal of Financial and Quantitative Analysis 37, 495-521.

Bauer, R., G. L. Clark, and D. Wójcik, 2004. Corporate Governance and Cross-Listing: Evidence from European Companies, University of Oxford Economic Geography Research Group Working Paper 04-24.

Bekaert, G. and C. R. Harvey, 2000. Foreign Speculators and Emerging Equity Markets, Journal of Finance 55, 565-613.

Bekaert, G. and C. R. Harvey, 2003. Emerging Markets Finance, Journal of Empirical Finance $10,3-55$.

Bekaert, G., C. R. Harvey, and C. Lundblad, 2001. Emerging Equity Markets and Economic Development, Journal of Development Economics 66, 465-504.

Bekaert, G., C. R. Harvey, and C. Lundblad, 2004. Does Financial Liberalization Spur Growth? Journal of Financial Economics, forthcoming.

Benos, E. and M. S. Weisbach, 2004. Private Benefits and Cross-Listings in the United States, Emerging Markets Review 5, 217-240.

Biddle, G. C. and S. M. Saudagaran, 1992. Financial Disclosure Levels and Foreign Stock Exchange Listing Decisions, Journal of International Financial Management and Accounting 4, 106-148.

Black, F., 1974. International Capital Market Equilibrium with Investment Barriers, Journal of Financial Economics 1, 337-352.

Blanchard, O. J., C. Rhee, and L. Summers, 1993. The Stock Market, Profit, and Investment, Quarterly Journal of Economics 108, 15-36.

Brennan, M. J. and A. Subrahmanyam, 1996. Market Microstructure and Asset Pricing: On the Compensation for Illiquidity in Stock Returns, Journal of Financial Economics 41, 441464. 
Cantale, S., 1996. The Choice of a Foreign Market as a Signal, Working Paper, Tulane University.

Chari, A. and P. B. Henry, 2002. Capital Account Liberalization: Allocative Efficiency or Animal Spirits? NBER Working Paper No. 8908.

Chari, A. and P. B. Henry, 2004. Risk Sharing and Asset Prices: Evidence from a Natural Experiment, Journal of Finance 59, 1295-1324.

Chowdhry, B. and V. Nanda, 1991. Multimarket Trading and Market Liquidity, Review of Financial Studies 4, 483-511.

Claessens, S., D. Klingebiel, and S. Schmukler, 2003. Which Firms Access International Stock Markets?, Working Paper, World Bank.

Claessens, S. and L. Laeven, 2003. Financial Development, Property Rights, and Growth, Journal of Finance 58, 2401-2436.

Coase, R. H., 1937. The Nature of the Firm, Economica 4, 386-405

Coffee, J., 1999. The Future as History: The Prospects for Global Convergence in Corporate Governance and its Implications, Northwestern Law Review 93, 641-708.

Coffee, J., 2002. Racing Towards the Top?: The Impact of Cross-Listings and Stock Market Competition on International Corporate Governance, Columbia Law Review 102, 17571831.

Doidge, C., 2004. U.S. Cross-Listings and the Private Benefits of Control: Evidence from Dualclass Firms, Journal of Financial Economics 72, 519-553.

Doidge, C. A., G. A. Karolyi, and R. M. Stulz, 2004. Why Are Firms that List in the U.S. Worth More?, Journal of Financial Economics 71, 205-238.

Domowitz, I., J. Glen, and A. Madhavan, 1998. International Cross-Listing and Order Flow Migration: Evidence from an Emerging Market, Journal of Finance 53, 2001-2027.

Edison, H., R. Levine, L. Ricci, and T. Slot, 2002. International Financial Integration and Economic Growth, Journal of International Money and Finance 21, 749-776.

Errunza, V., and E. Losq, 1985. International Asset Pricing Under Mild Segmentation: Theory and Tests, Journal of Finance 40, 105-124.

Errunza, V., and D. Miller, 2000. Market Segmentation and the Cost of Capital in International Equity Markets, Journal of Financial and Quantitative Analysis 35, 577-600.

Foerster, S., and G. A. Karolyi, 1998. Multimarket Trading and Liquidity: A Transaction Data Analysis of Canada-U.S. Interlistings, Journal of International Financial Markets, Institutions and Money 8, 393-412.

Foerster, S. and G. A. Karolyi, 1999. The Effects of Market Segmentation and Investor Recognition on Asset Prices: Evidence from Foreign Stocks Listing in the United States, Journal of Finance 54, 981-1013.

Foerster, S. and G. A. Karolyi, 2000. The Long-Run Performance of Global Equity Offerings, Journal of Financial and Quantitative Analysis 35, 499-528. 
Fuerst, O., 1998. A Theoretical Analysis of the Investor Protection Regulations Argument for Global Listing of Stocks, Working Paper, Yale University.

Greene, E., A. Beller, E. Rosen, L. Silverman, D. Braverman, and S. Sperber, 2000. U.S. Regulation of the International Securities and Derivatives Markets, Aspen Law and Business, New York.

Grinblatt, M. and M. Keloharju, 2001. How Distance, Language, and Culture Influence Stockholdings and Trades, Journal of Finance 56, 1053-1073.

Hart, O., 1995. Firms, Contracts, and Financial Structure, Oxford University Press, London.

Henderson, B. J., N. Jegadeesh, and M. S. Weisbach, 2004. World Markets for Raising New Capital, NBER Working Paper No. 10225.

Henry, P. B., 2000a. Stock Market Liberalization, Economic Reform, and Emerging Market Equity Prices, Journal of Finance 55, 529-564.

Henry, P. B., 2000b. Do Stock Market Liberalizations Cause Investment Booms? Journal of Financial Economics 58, 301-334.

Henry, P. B., 2003. Capital Account Liberalization, The Cost of Capital, and Economic Growth, American Economic Review 93, 91-96.

Huberman, G., 2001. Familiarity Breeds Investment, Review of Financial Studies 14, 659-680.

Huddart, S., J. Hughes, and M. Brunnermeier, 1999. Disclosure Requirements and Stock Exchange Listing Choice in an International Context, Journal of Accounting and Economics 26, 237-269.

Jayaraman, N., K. Shastri, and K. Tandon, 1993. The Impact of International Cross-Listings on Risk and Return: The Evidence from American Depositary Receipts, Journal of Banking and Finance 17, 91-103.

Jensen, M., and W. Meckling, 1976. Theory of the Firm: Managerial Behavior, Agency Costs, and Ownership Structure, Journal of Financial Economics 3, 305-360.

Kang, J., and R. M. Stulz, 1997. Why Is There a Home Bias? An Analysis of Foreign Portfolio Equity Ownership in Japan, Journal of Financial Economics 46, 3-28.

Karolyi, A. and R. M. Stulz, 2003. Are Assets Priced Locally or Globally? in G. Constantinides, M. Harris, and R. M. Stulz (eds.), The Handbook of the Economics of Finance, North Holland.

Klapper, L. F. and I. Love, 2004. Corporate Governance, Investor Protection, and Performance in Emerging Markets, Journal of Corporate Finance 10, 703-728.

Lang, M., V. Lins, and D. Miller, 2003. ADRs, Analysts, and Accuracy. Does Cross Listing in the United States Improve a Firm's Information Environment and Increase Market Value? Journal of Accounting Research 41, 317-345.

Lang, M., J. S. Raedy, and M. Yetman, 2003. How Representative Are Cross-Listed Firms? An Analysis of Firm Performance and Accounting Quality, Journal of Accounting Research 41, 363-386. 
La Porta, R., F. Lopez-de-Silanes, A. Shleifer, and R. Vishny, 2002. Investor Protection and Corporate Valuation, Journal of Finance 57, 1147-1170.

Lau, S. T., J. D. Diltz, and V. P. Apilado, 1994. Valuation Effects of International Stock Exchange Listings, Journal of Banking and Finance 18, 743-755.

Levine, R. and S. Schmukler, 2003. Migration, Spillovers, and Trade Diversion: The Impact of Internationalization on Domestic Stock Market Liquidity. NBER Working Paper No. 9614.

Levine, R. and S. Zervos, 1998a. Capital Control Liberalization and Stock Market Development, World Development 26, 1169-1183.

Levine, R. and S. Zervos, 1998b. Stock Markets, Banks, and Economic Growth, American Economic Review 88, 537-558.

Licht, A. N., 2003. Cross-Listing and Corporate Governance: Bonding or Avoiding?, Chicago Journal of International Law 4, 141-163.

Licht, A. N, 2004. Legal Plug-Ins: Cultural Distance, Cross-Listing, and Corporate Governance Reform, Berkeley Journal of International Law 22, 159.

Madhavan, A., 1995. Consolidation, Fragmentation, and the Disclosure of Trading Information, Review of Financial Studies 8, 579-603.

Merton, R.C., 1987. A Simple Model of Capital Market Equilibrium with Incomplete Information, Journal of Finance 42, 483-510.

Miller, D., 1999. The Market Reaction to International Cross-Listings: Evidence from Depositary Receipts, Journal of Financial Economics 51, 103-123.

Moel, A., 2000. The Role of Information Disclosure on Stock Market Listing Decisions: The Case of Foreign Firms Listing in the U.S., Working Paper, Harvard Business School.

Pagano, M., 1989. Trading Volume and Asset Liquidity, Quarterly Journal of Economics 104, 255-274.

Pagano, M., O. Randl, A. Röell, and J. Zechner, 2001. What Makes Stock Exchanges Succeed? Evidence from Stock Listing Decisions, European Economic Review 45, 770-782.

Pagano M., A. Röell, and J. Zechner, 2002. The Geography of Equity Listing: Why Do Companies List Abroad? Journal of Finance 57, 2651-2694.

Patro, D. K. and J. K. Wald, 2004. Firm Characteristics and the Impact of Emerging Market Liberalizations, Journal of Banking and Finance, forthcoming.

Pinegar, J. M. and R. Ravichandran, 2003. U.S. Investors' Perceptions of Corporate Control in Mexico: Evidence from Sibling ADRs, Journal of Financial and Quantitative Analysis 38, 213-230.

Reese, W. A. Jr. and M. S. Weisbach, 2002. Protection of Minority Shareholder Interests, Crosslisting in the United States, and Subsequent Equity Offerings, Journal of Financial Economics 66, 65-104. 
Sarkissian, M. and M. J. Schill, 2003. Are There Permanent Valuation Gains to Overseas Listing? Evidence from Market Sequencing and Selection, Darden Graduate School of Business Administration University of Virginia, Working Paper No. 03-03.

Sarkissian, M. and M. J. Schill, 2004. The Overseas Listing Decision: New Evidence of Proximity Preference, Review of Financial Studies 17, 769-809.

Schmukler, S. and E. Vesperoni, 2003. Financial Globalization and Debt Maturity in Emerging, Journal of Development Economics, forthcoming.

Shin, H. and R. M. Stulz, 2000. Firm Value, Risk, and Growth Opportunities, NBER Working Paper No. 7808.

Siegel, J., 2004. Can Foreign Firms Bond Themselves Effectively by Renting U.S. Securities Laws?, Journal of Financial Economics, forthcoming.

Smith K., and G. Sofianos, 1997. The Impact of an NYSE Listing on the Global Trading of NonU.S. Stocks, NYSE Working Paper 97-02.

Solnik, B., 1974. An Equilibrium Model of the International Capital Market, Journal of Economic Theory 18, 365-378.

Stapleton, R. and M. Subrahmanyam, 1977. Market Imperfections, Capital Market Equilibrium, and Corporate Finance, Journal of Finance 32, 307-319.

Stulz, R., 1981, On the Effects of Barriers to International Asset Pricing, Journal of Finance 25, 783-794.

Stulz, R. M., 1999. Globalization of Equity Markets and the Cost of Capital, Journal of Applied Corporate Finance 12, 1-12.

Werner, I., and A. Kleidon, 1996. U.S. and U.K. Trading of British Cross-Listed Stocks: An Intraday Analysis of Market Integration, Review of Financial Studies 9, 619-664. 


\section{Figure 1}

\section{Tobin's $Q$ of Domestic and International Firms}

The top panel displays the average Tobin's $q$ of domestic and international firms over the whole sample period. The bottom panel shows the average Tobin's $q$ of international firms before and after internationalization. International firms are those identified as having at least one active depositary receipt program, having raised equity capital in international markets, or trading in the London Stock Exchange, NASDAQ, or NYSE.

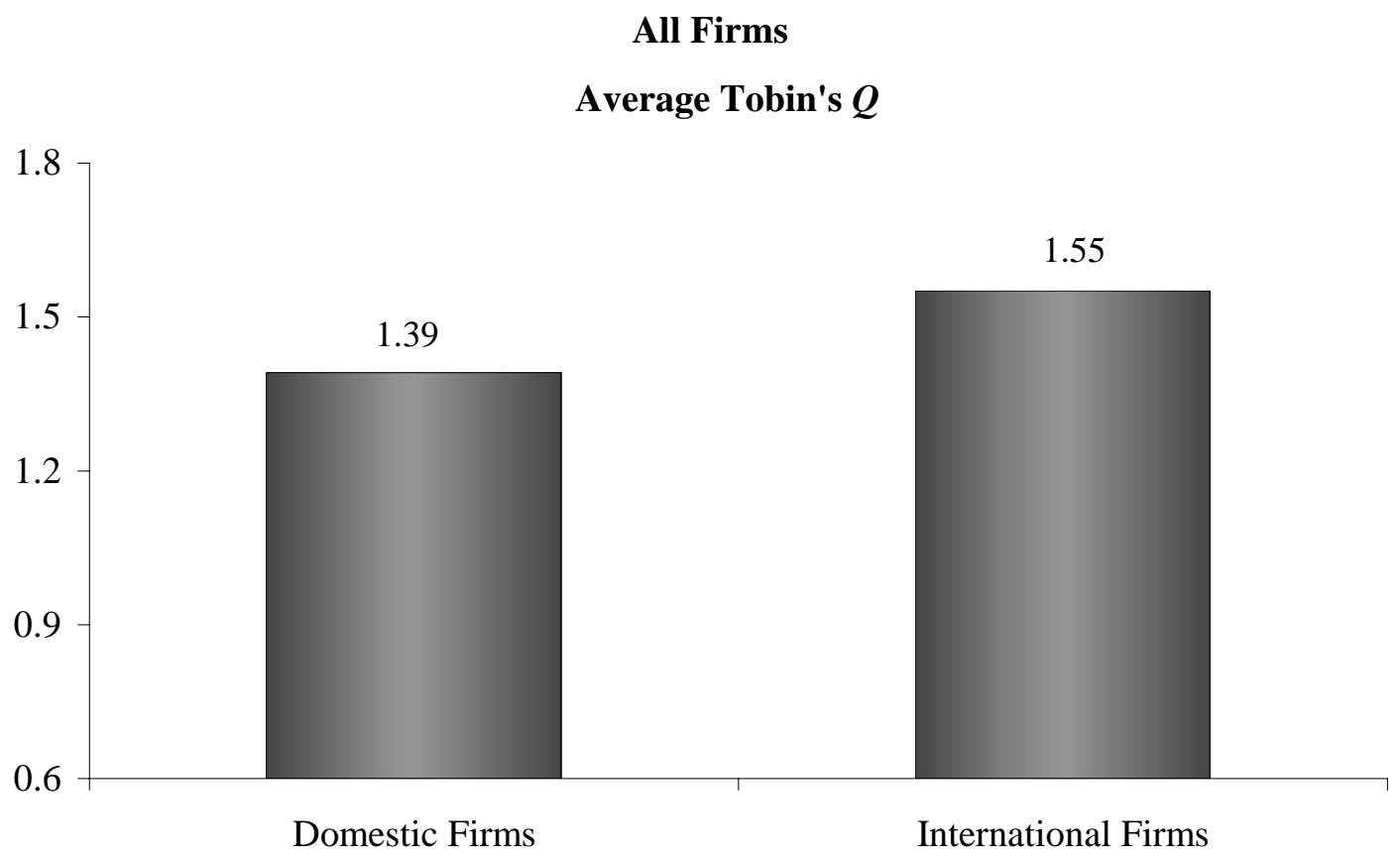

\section{International Firms}

Average Tobin's $Q$

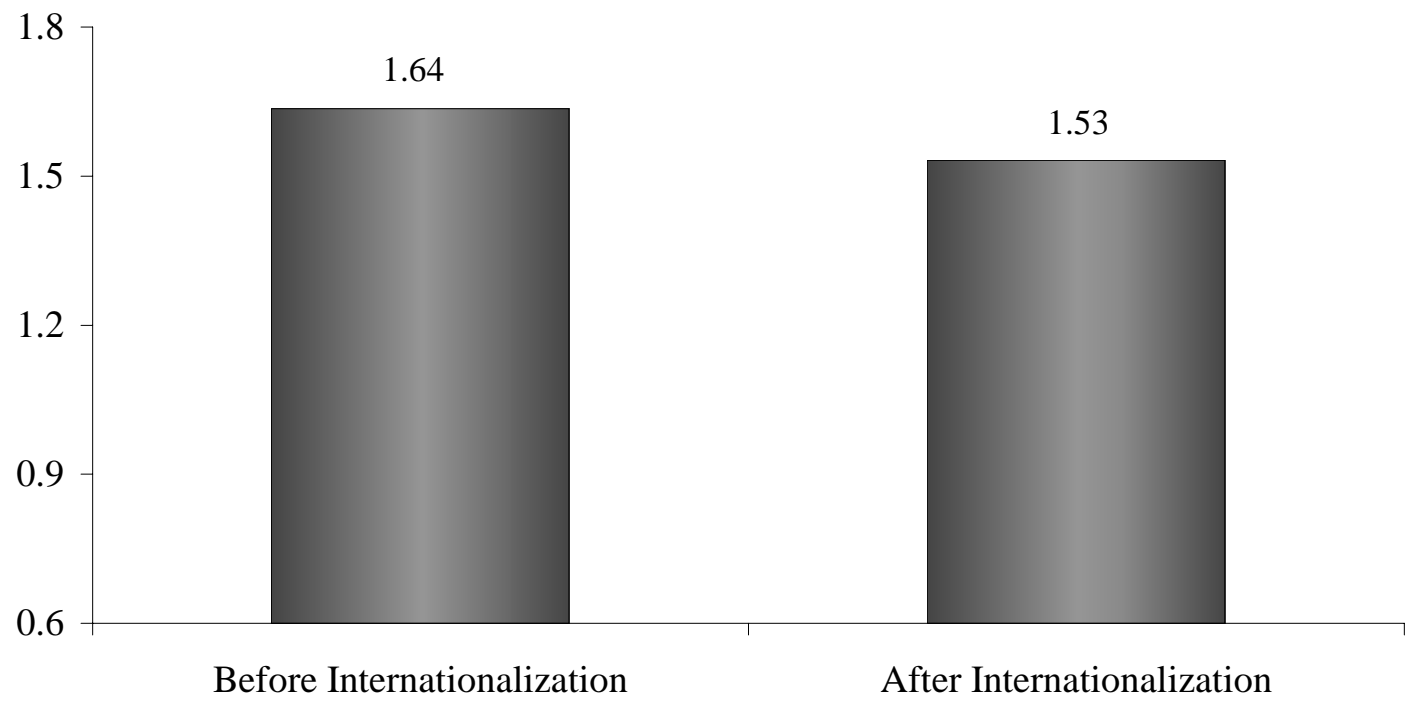


Figure 2

Internationalization and the Evolution of Tobin's $Q$

The top panel shows the evolution of Tobin's $q$ of international firms around internationalization. The data are the average Tobin's $q$ in each year around the internationalization date (date zero). The bottom panel shows the evolution of the relative Tobin's $q$ of international firms, defined as the Tobin's $q$ of each international firm over the average Tobin's $q$ of all domestic firms in the firm's home country. The data are the average relative Tobin's $q$ in each year around the internationalization date (date zero). International firms are those identified as having at least one active depositary receipt program, having raised equity capital in international markets, or trading in the London Stock Exchange, NYSE, or NASDAQ.

Tobin's $Q$

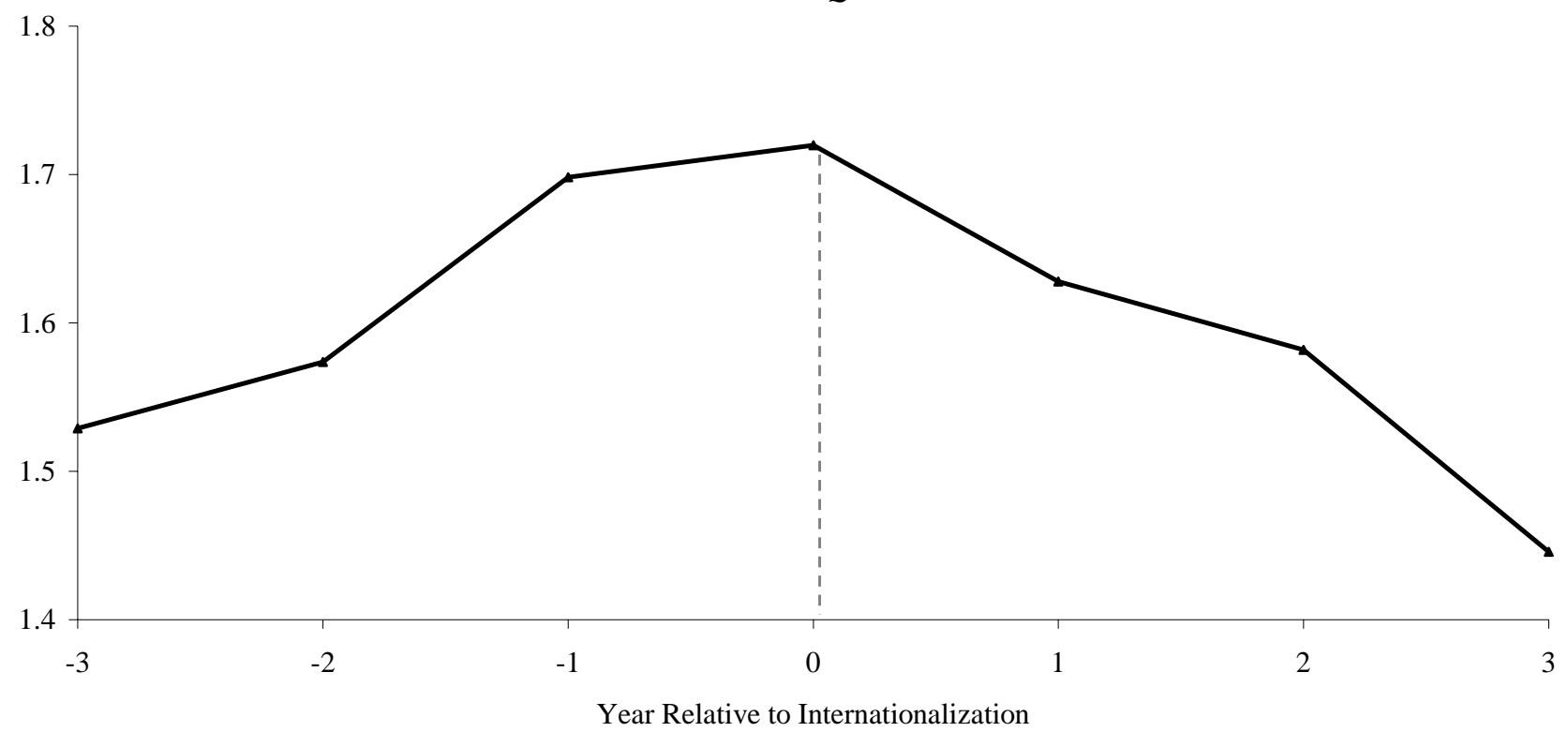

Relative Tobin's $Q$

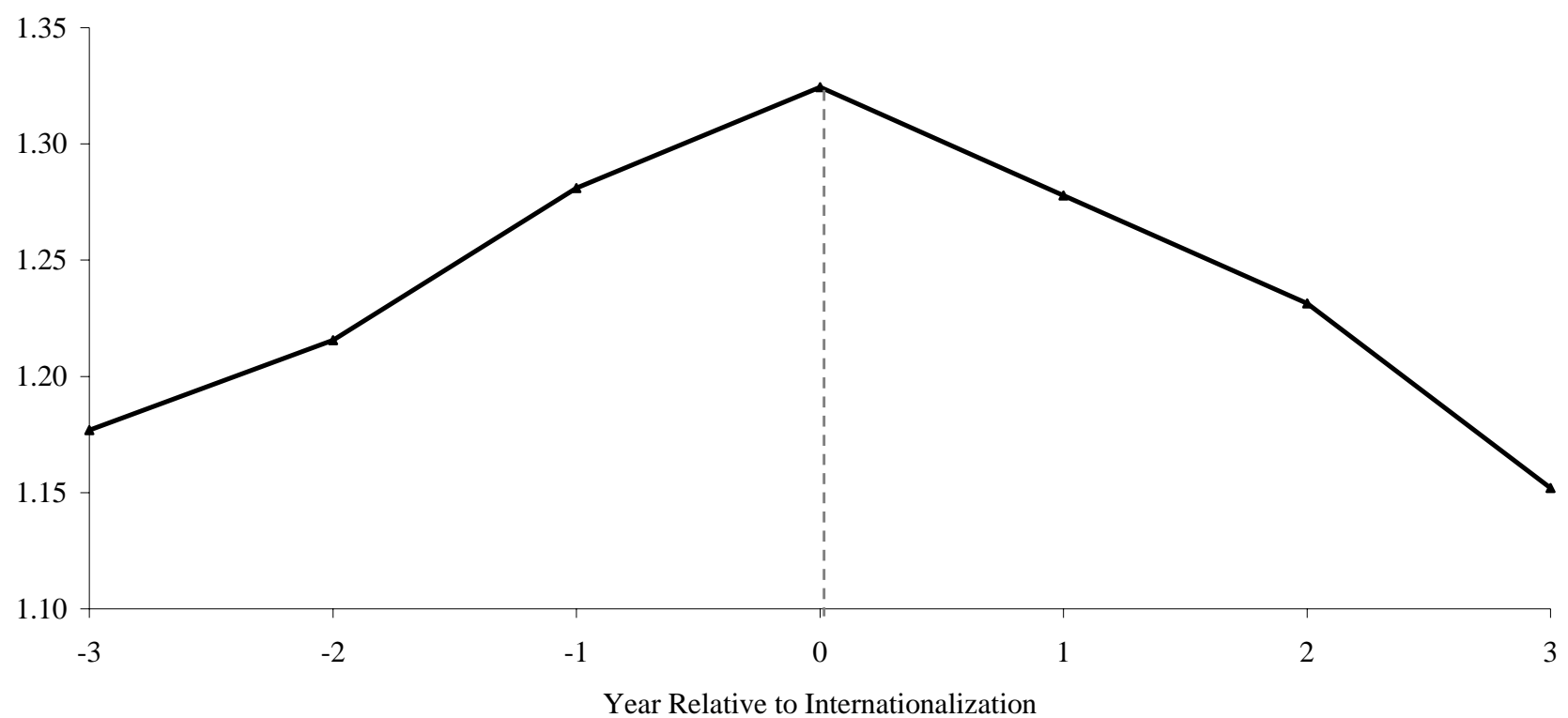




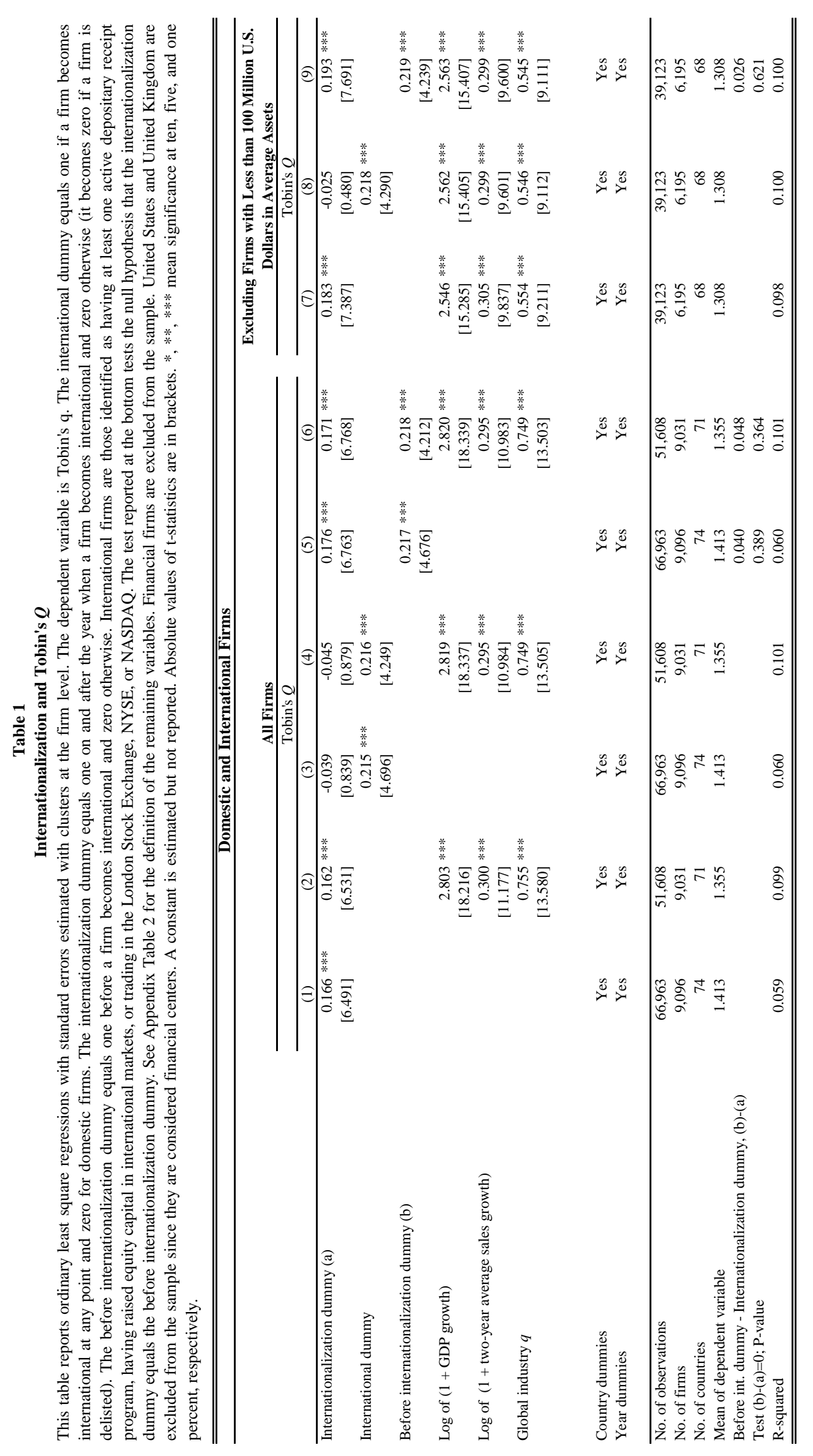




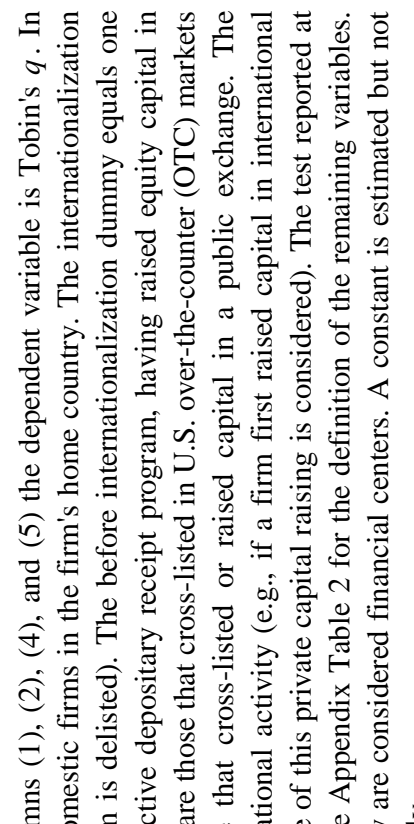

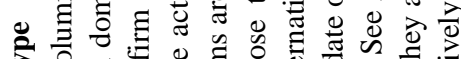

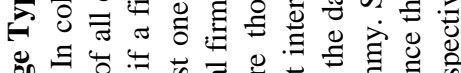

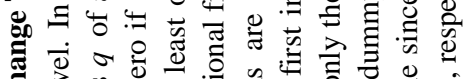

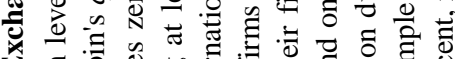

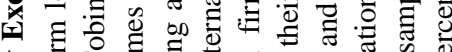

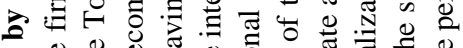

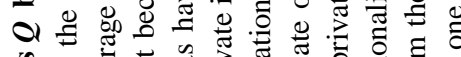
을

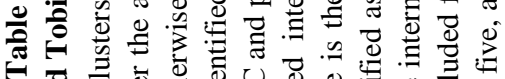

音

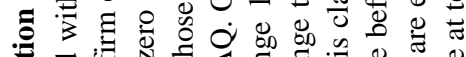

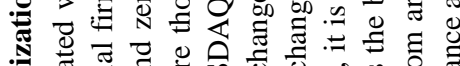

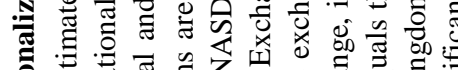

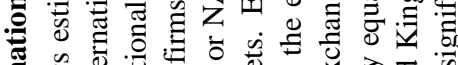

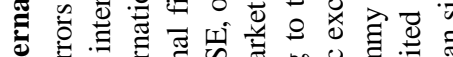
严

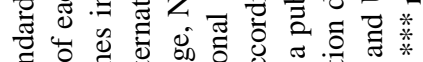

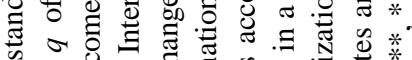

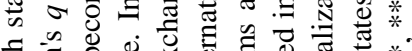

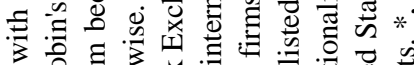

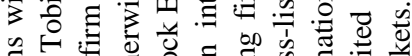

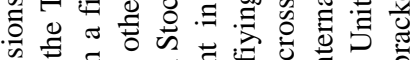

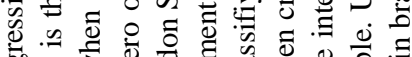

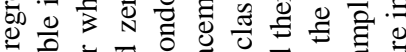
迸

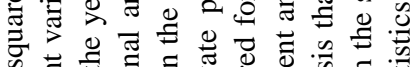
to

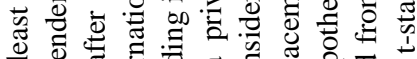

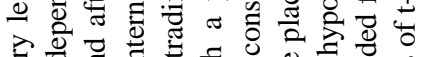

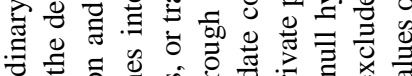

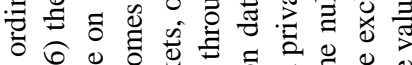

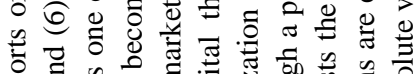

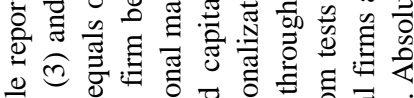

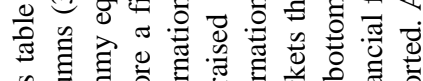

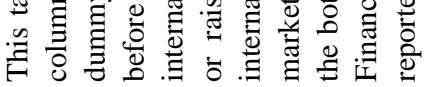

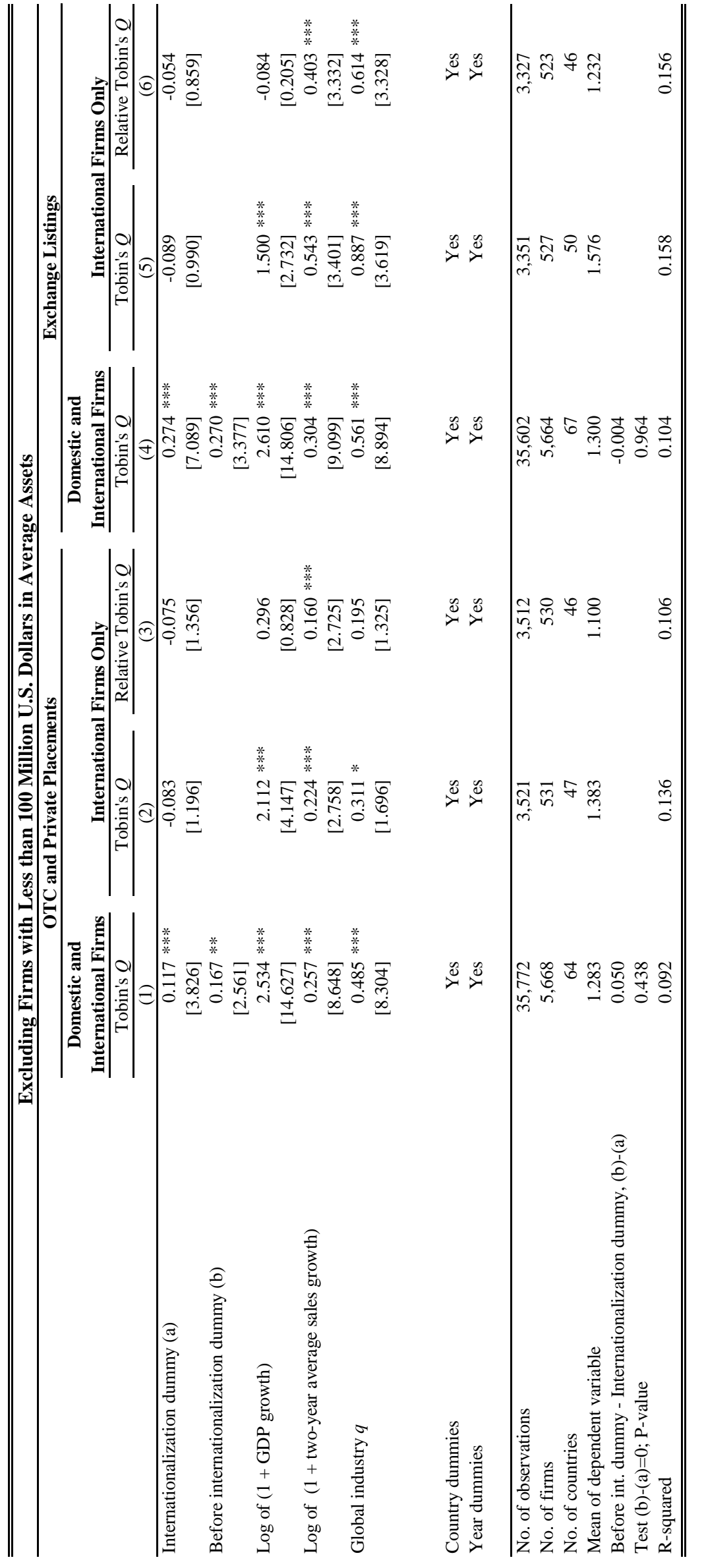




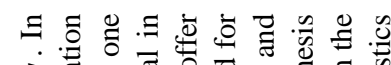
o

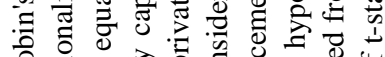

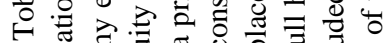

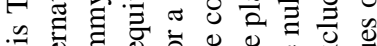

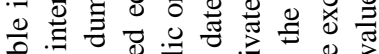

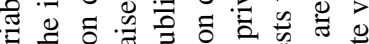

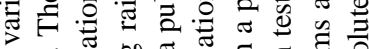

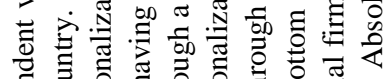
过 웡

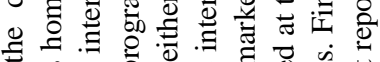

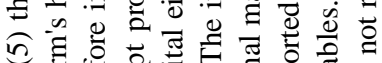

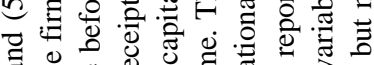
击 宇.

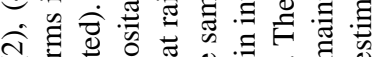

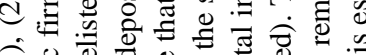

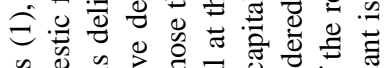

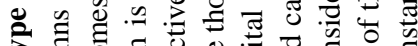

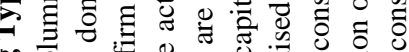

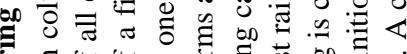

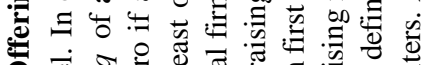

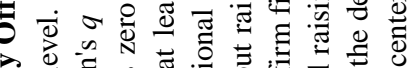

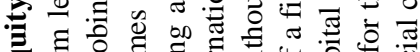

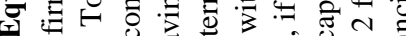

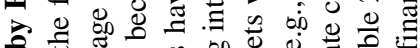

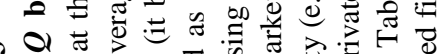

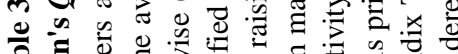

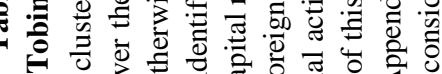

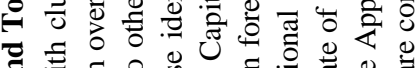

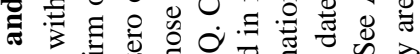

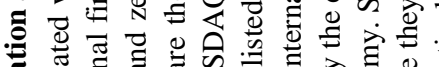

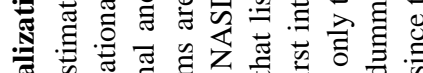

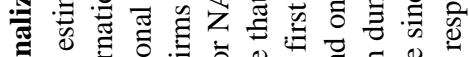
은

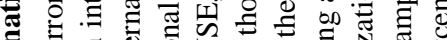

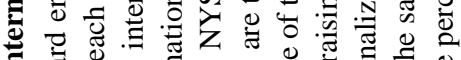

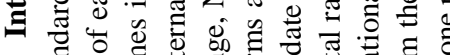
矛

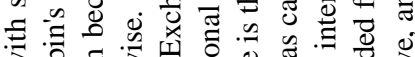

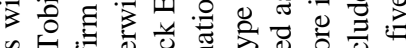

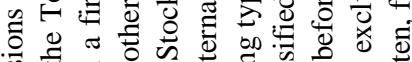

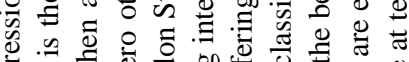

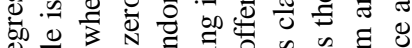

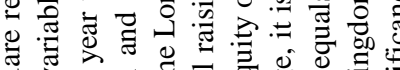

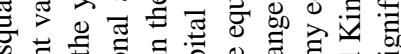
एक्ष

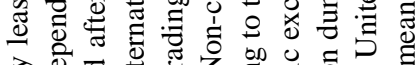

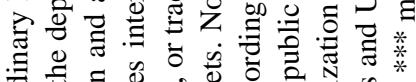

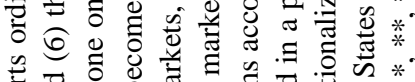

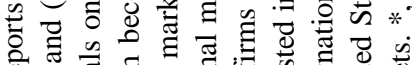

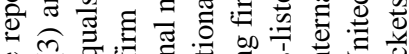

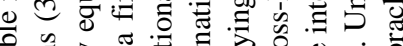
ฐ

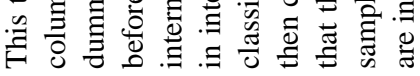

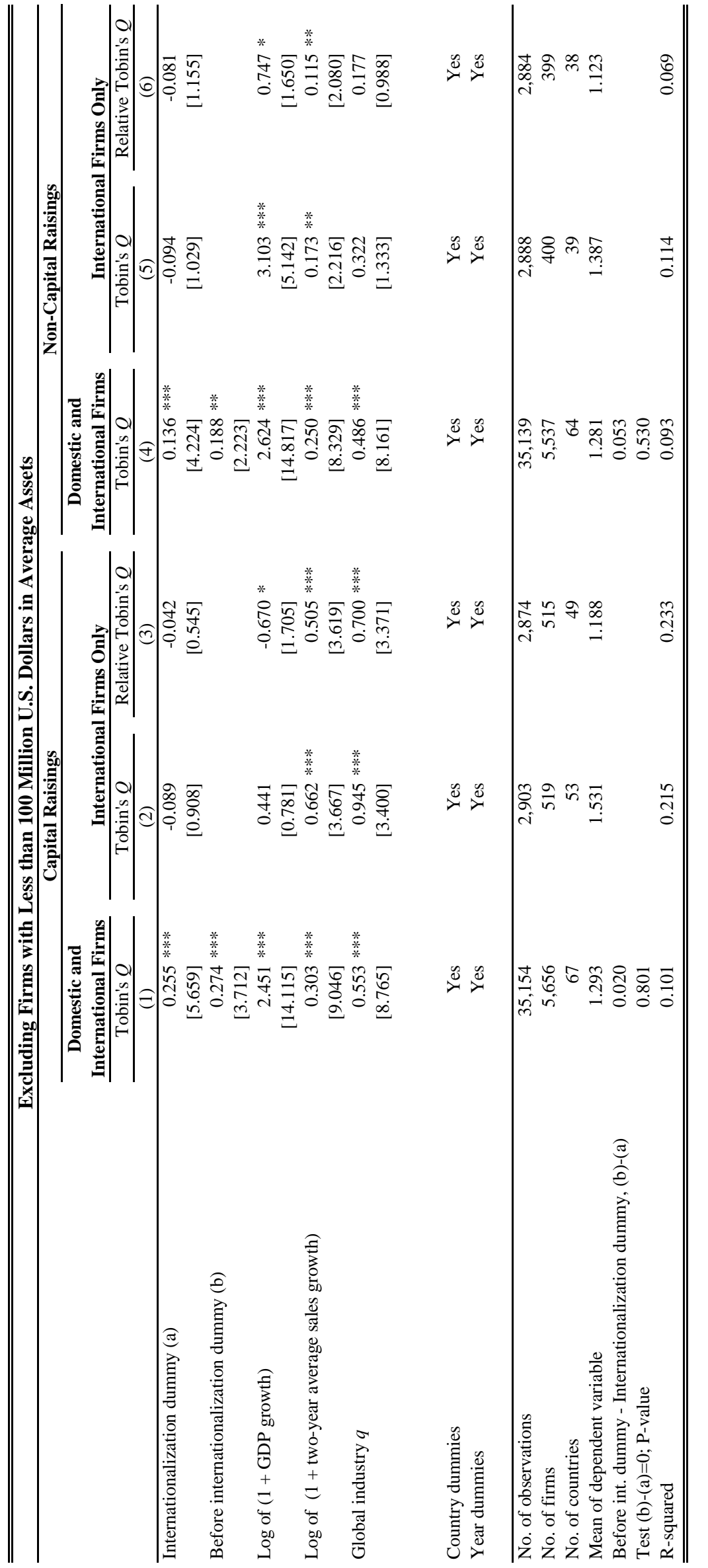


$\Xi$ 。ี

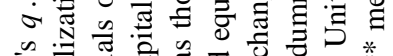

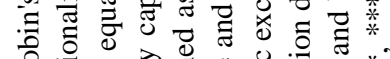

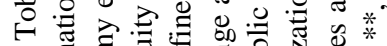

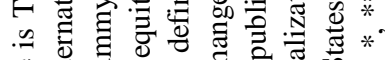

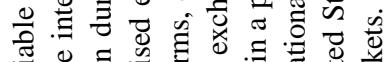

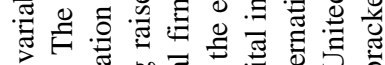

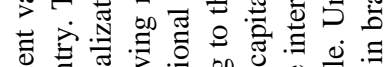

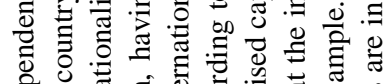

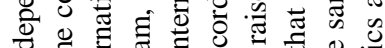

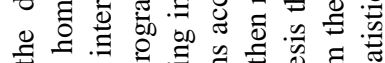
- क

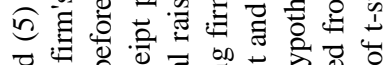
उ

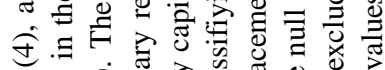

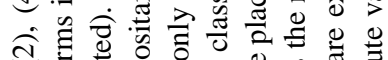

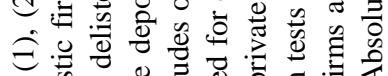

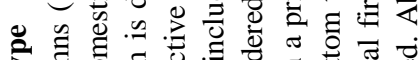

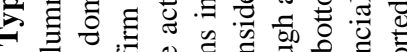

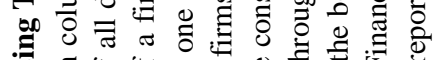

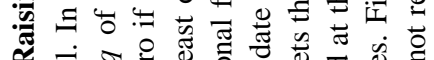

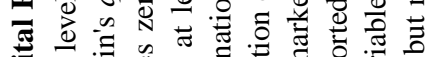

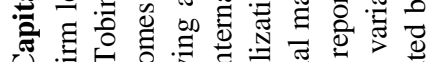

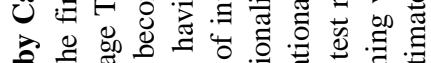

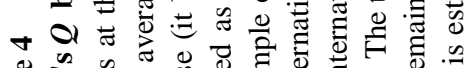

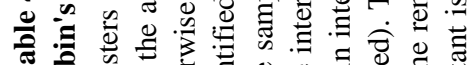

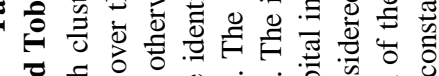

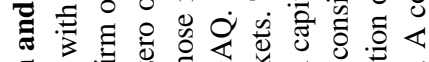

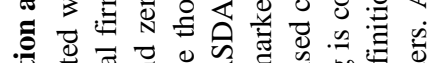

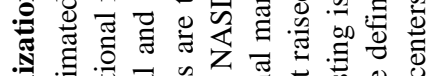

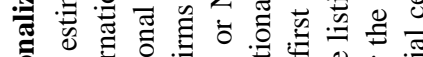

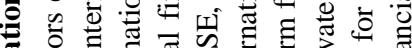

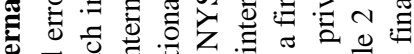

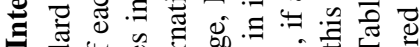

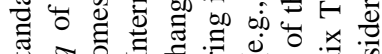
के of

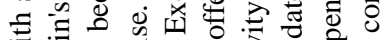

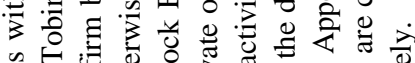
ठ응 के

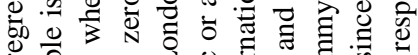

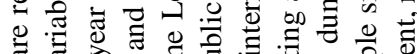
羟

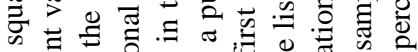

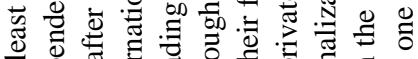

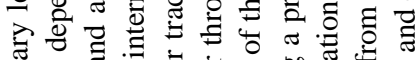

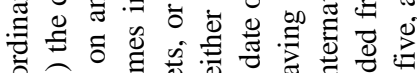

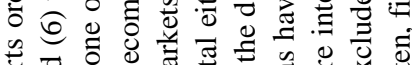

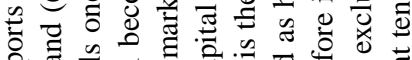

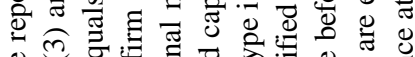

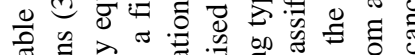

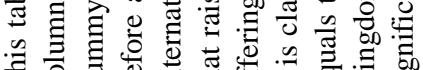

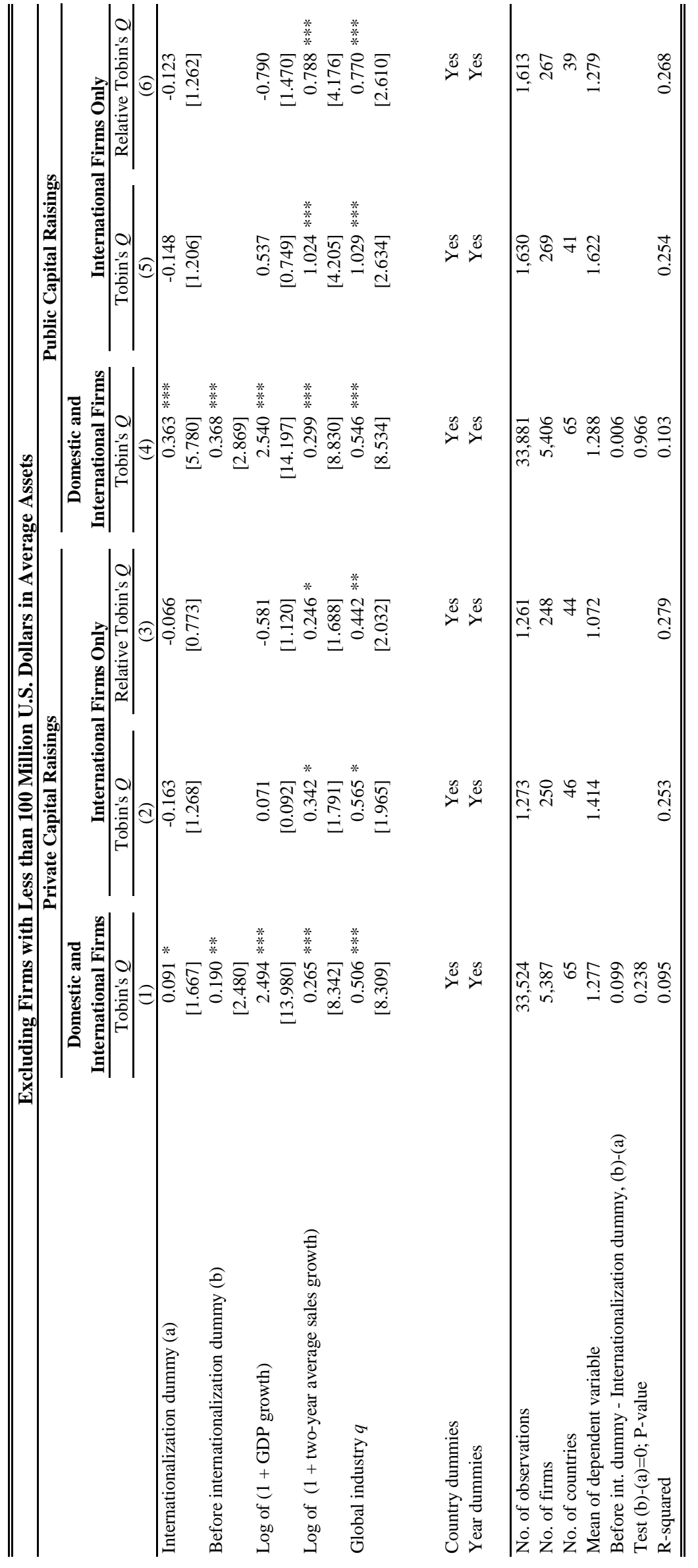


ヨ.

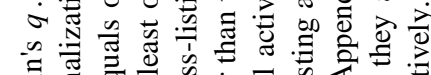

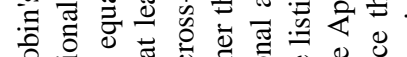

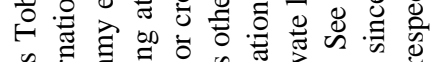

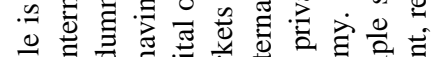

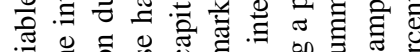
急怘.

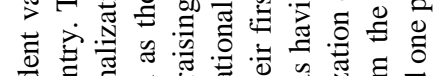

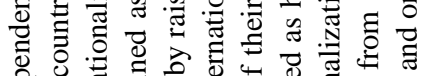
过

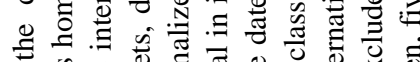

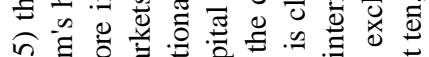

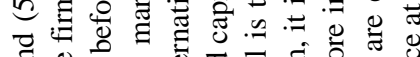

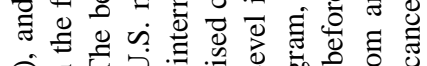
过.

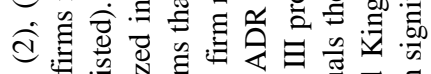

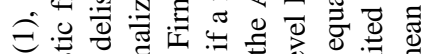
की

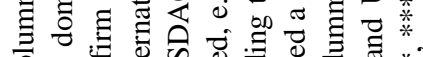

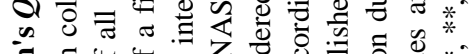

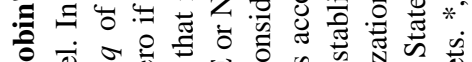

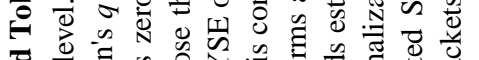

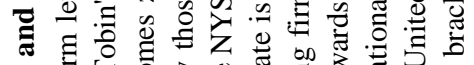
의

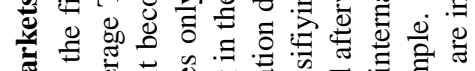

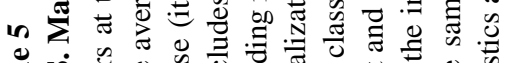

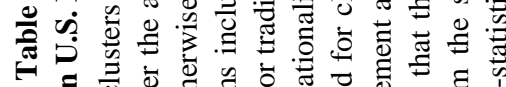

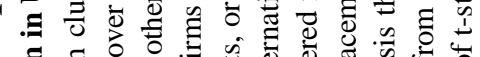

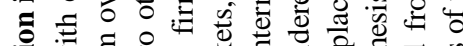

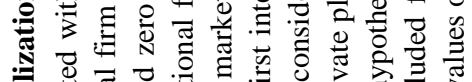

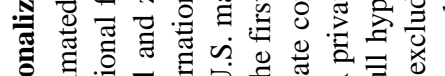

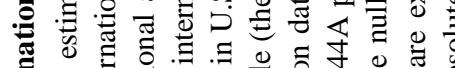

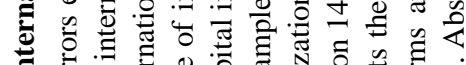

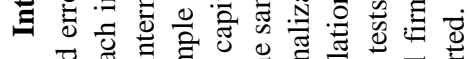
उ

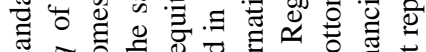

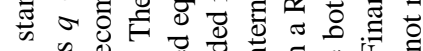

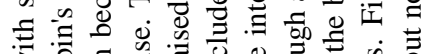

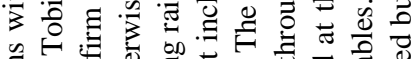
完

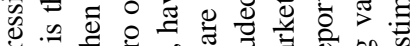

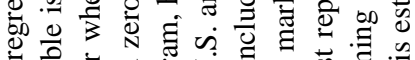

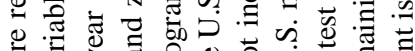
형

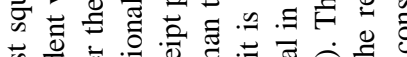

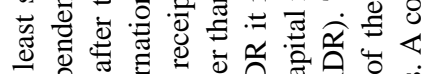

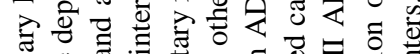
朵宅

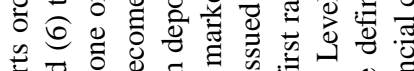

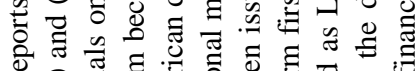

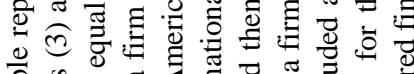

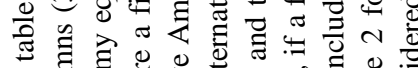

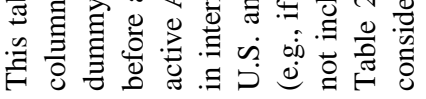

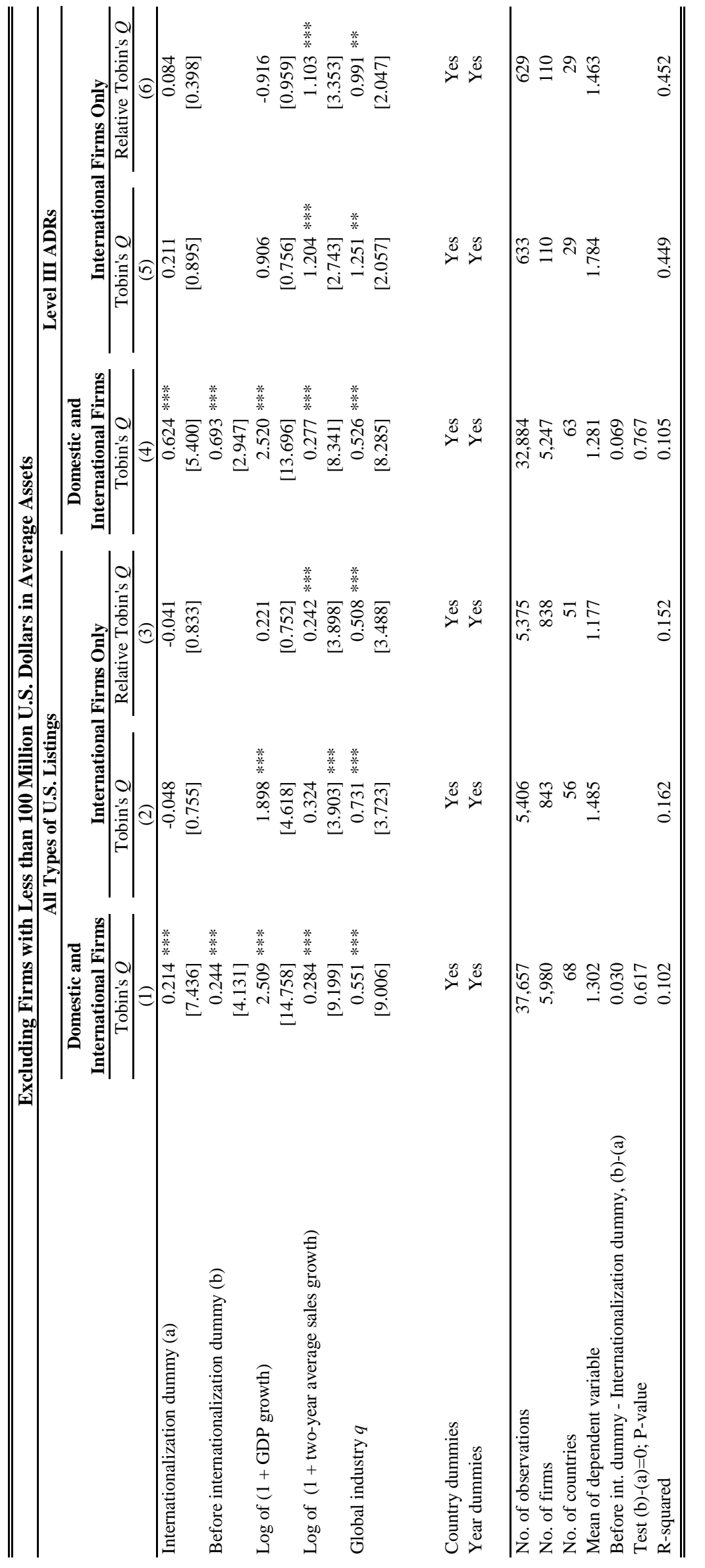




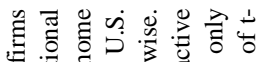

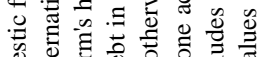

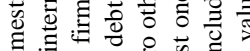

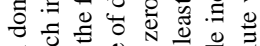

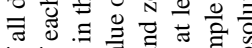

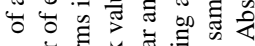

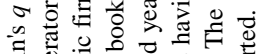

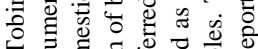

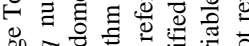

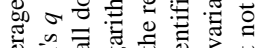

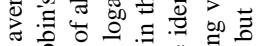

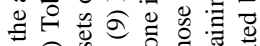

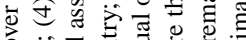

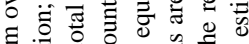
自究

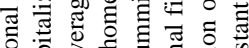

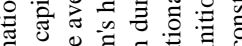

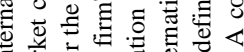

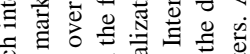
ङ

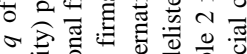
क 응

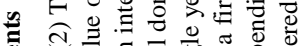
枃

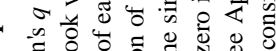

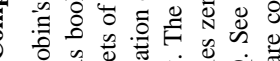

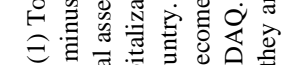
웡 a 00 क्ष

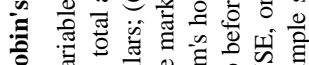

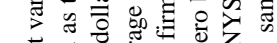

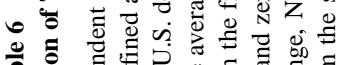

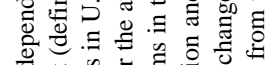

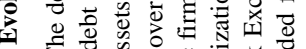
要

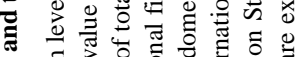

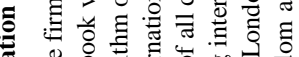

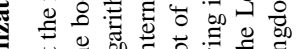
的正

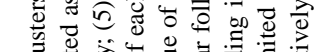

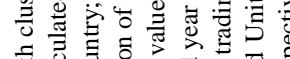

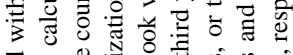

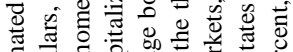

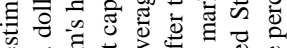

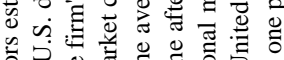

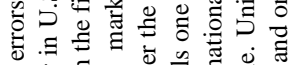

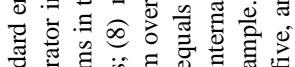

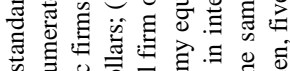

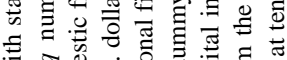
药 on

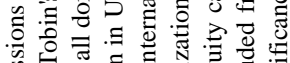
证

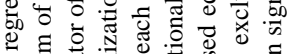

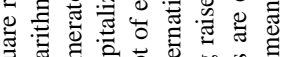

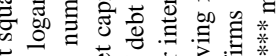
急

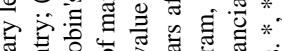

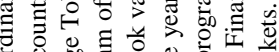

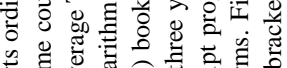
语

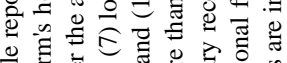

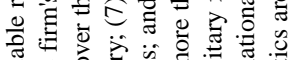

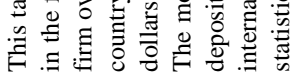

竞

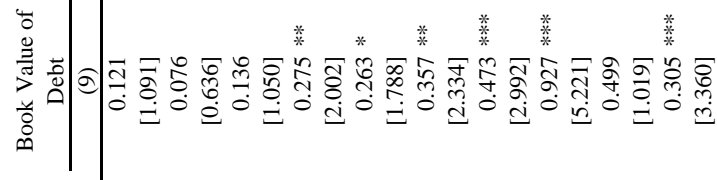

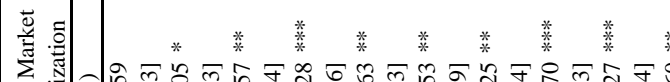

※゙

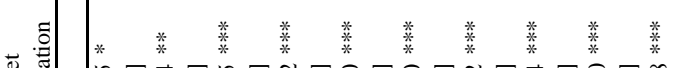

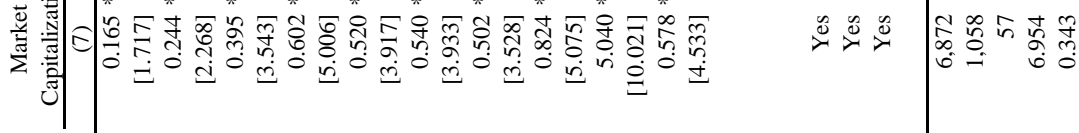

焉

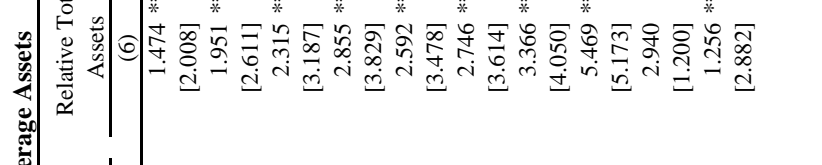

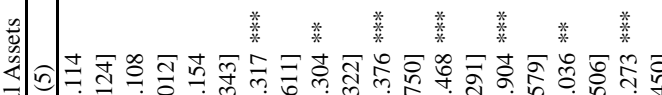

㩊

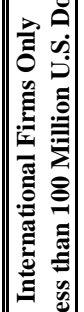

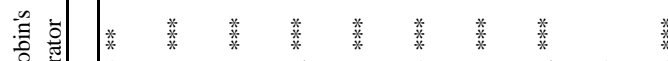

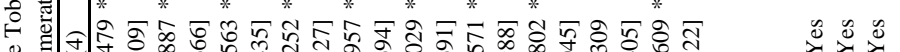

焉

a

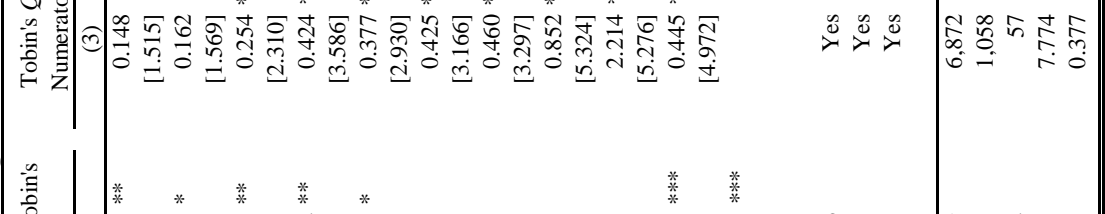

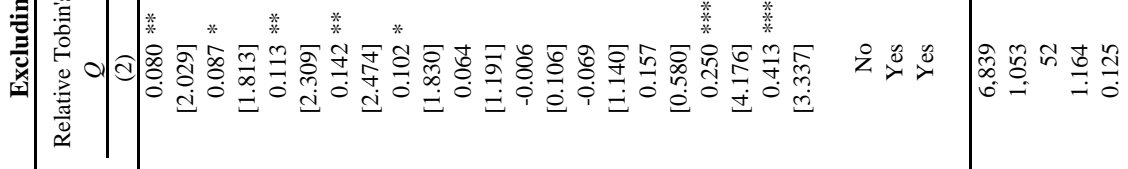
青|

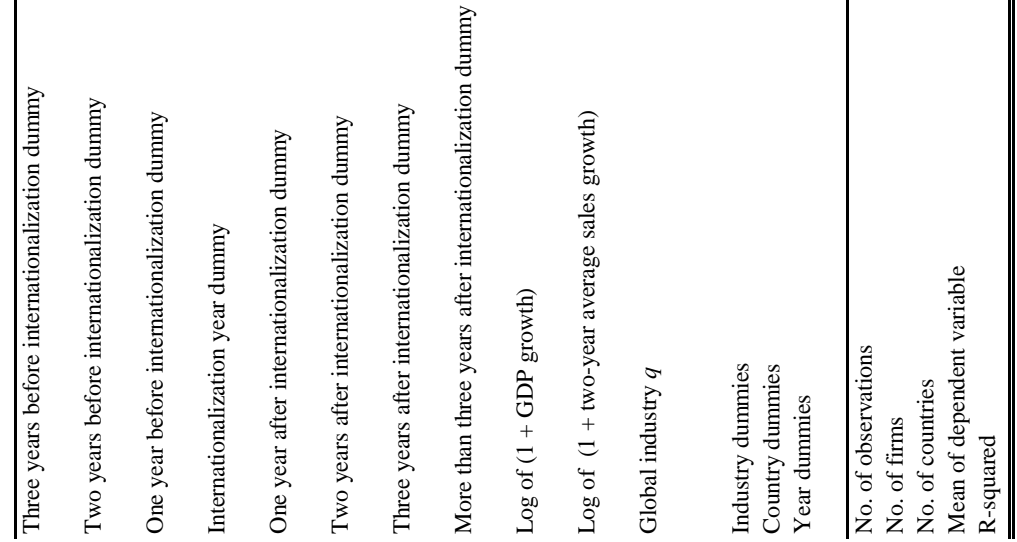




\section{Appendix Table 1 \\ Basic Statistics}

This table reports summary statistics by country. It displays the total number of firms, the number of international firms, the number of domestic firms, the sample coverage, and the sample average of Tobin's $q$. International firms are those identified as having at least one active depositary receipt program, having raised equity capital in international markets, or trading in the London Stock Exchange, NYSE, or NASDAQ.

\begin{tabular}{|c|c|c|c|c|c|c|c|c|}
\hline & Country & $\begin{array}{c}\text { Number of } \\
\text { Firms }\end{array}$ & $\begin{array}{c}\text { Number of } \\
\text { Domestic } \\
\text { Firms } \\
\end{array}$ & $\begin{array}{c}\text { Number of } \\
\text { International } \\
\text { Firms } \\
\end{array}$ & $\begin{array}{l}\text { Sample } \\
\text { Period }\end{array}$ & Tobin's $Q$ & $\begin{array}{c}\text { Tobin's } Q \text { of } \\
\text { Domestic } \\
\text { Firms } \\
\end{array}$ & $\begin{array}{c}\text { Tobin's } Q \text { of } \\
\text { International } \\
\text { Firms } \\
\end{array}$ \\
\hline 1 & Argentina & 42 & 27 & 15 & $1989-2000$ & 1.11 & 1.04 & 1.23 \\
\hline 2 & Australia & 219 & 161 & 58 & $1989-2000$ & 1.51 & 1.49 & 1.55 \\
\hline 3 & Austria & 71 & 55 & 16 & $1989-2000$ & 1.33 & 1.32 & 1.37 \\
\hline 4 & Bahamas & 1 & 0 & 1 & $1996-2000$ & 1.08 & - & 1.08 \\
\hline 5 & Belgium & 97 & 84 & 13 & $1989-2000$ & 1.59 & 1.50 & 2.48 \\
\hline 6 & Bermuda & 1 & 1 & 0 & $1996-1999$ & 1.11 & 1.11 & - \\
\hline 7 & Botswana & 2 & 2 & 0 & $1996-2000$ & 1.87 & 1.87 & - \\
\hline 8 & Brazil & 137 & 94 & 43 & $1989-2000$ & 0.91 & 0.91 & 0.91 \\
\hline 9 & Bulgaria & 6 & 5 & 1 & $1998-2000$ & 1.57 & 1.78 & 0.52 \\
\hline 10 & Canada & 516 & 390 & 126 & $1989-2000$ & 1.57 & 1.43 & 1.94 \\
\hline 11 & Channel Islands & 1 & 1 & 0 & $1991-1998$ & 1.54 & 1.54 & - \\
\hline 12 & Chile & 88 & 71 & 17 & $1989-2000$ & 1.41 & 1.34 & 1.61 \\
\hline 13 & China & 115 & 70 & 45 & $1992-2000$ & 1.42 & 1.56 & 1.15 \\
\hline 14 & Colombia & 18 & 15 & 3 & $1989-2000$ & 0.99 & 0.97 & 1.11 \\
\hline 15 & Cote d'Ivoire & 1 & 1 & 0 & $1998-2000$ & 2.28 & 2.28 & - \\
\hline 16 & Croatia & 2 & 1 & 1 & $1997-2000$ & 1.36 & 0.63 & 2.08 \\
\hline 17 & Czech Republic & 28 & 26 & 2 & $1995-2000$ & 0.96 & 0.87 & 1.83 \\
\hline 18 & Denmark & 150 & 145 & 5 & $1989-2000$ & 1.38 & 1.36 & 1.83 \\
\hline 19 & Egypt & 4 & 1 & 3 & $1997-2000$ & 2.02 & 1.38 & 2.21 \\
\hline 20 & Estonia & 4 & 4 & 0 & $1997-2000$ & 1.10 & 1.10 & - \\
\hline 21 & Finland & 96 & 77 & 19 & $1989-2000$ & 1.30 & 1.33 & 1.21 \\
\hline 22 & France & 560 & 511 & 49 & $1989-2000$ & 1.39 & 1.36 & 1.61 \\
\hline 23 & Germany & 526 & 491 & 35 & $1989-2000$ & 1.55 & 1.54 & 1.59 \\
\hline 24 & Ghana & 4 & 3 & 1 & $1996-2000$ & 1.08 & 1.03 & 1.23 \\
\hline 25 & Greece & 124 & 119 & 5 & $1989-2000$ & 2.09 & 2.10 & 1.78 \\
\hline 26 & Hong Kong & 228 & 155 & 73 & $1989-2000$ & 1.29 & 1.21 & 1.45 \\
\hline 27 & Hungary & 22 & 8 & 14 & $1992-2000$ & 1.39 & 1.37 & 1.40 \\
\hline 28 & India & 293 & 233 & 60 & $1990-2000$ & 1.65 & 1.70 & 1.45 \\
\hline 29 & Indonesia & 93 & 85 & 8 & $1989-2000$ & 1.34 & 1.33 & 1.44 \\
\hline 30 & Ireland & 58 & 27 & 31 & $1989-2000$ & 1.55 & 1.48 & 1.60 \\
\hline 31 & Israel & 41 & 23 & 18 & $1993-2000$ & 1.43 & 1.18 & 1.71 \\
\hline 32 & Italy & 135 & 114 & 21 & $1989-2000$ & 1.29 & 1.24 & 1.56 \\
\hline 33 & Jamaica & 2 & 2 & 0 & $1998-2000$ & 0.84 & 0.84 & - \\
\hline 34 & Japan & 2,647 & 2,533 & 114 & $1989-2000$ & 1.34 & 1.34 & 1.42 \\
\hline 35 & Jordan & 1 & 0 & 1 & $1997-2000$ & 1.27 & - & 1.27 \\
\hline 36 & Kenya & 9 & 9 & 0 & $1996-2000$ & 1.24 & 1.24 & - \\
\hline 37 & Latvia & 5 & 4 & 1 & $1997-2000$ & 0.72 & 0.70 & 0.80 \\
\hline 38 & Liechtenstein & 1 & 1 & 0 & $1989-2000$ & 1.42 & 1.42 & - \\
\hline
\end{tabular}




\section{Appendix Table 1 (Continued) \\ Basic Statistics}

This table reports summary statistics by country. It displays the total number of firms, the number of international firms, the number of domestic firms, the sample coverage, and the sample average of Tobin's $q$. International firms are those identified as having at least one active depositary receipt program, having raised equity capital in international markets, or trading in the London Stock Exchange, NYSE, or NASDAQ.

\begin{tabular}{|c|c|c|c|c|c|c|c|c|}
\hline & Country & $\begin{array}{c}\text { Number of } \\
\text { Firms }\end{array}$ & $\begin{array}{c}\text { Number of } \\
\text { Domestic } \\
\text { Firms } \\
\end{array}$ & $\begin{array}{c}\text { Number of } \\
\text { International } \\
\text { Firms } \\
\end{array}$ & $\begin{array}{l}\text { Sample } \\
\text { Period }\end{array}$ & Tobin's $Q$ & $\begin{array}{c}\text { Tobin's } Q \text { of } \\
\text { Domestic } \\
\text { Firms } \\
\end{array}$ & \begin{tabular}{|c|} 
Tobin's $Q$ of \\
International \\
Firms \\
\end{tabular} \\
\hline 39 & Lithuania & 3 & 3 & 0 & $1996-2000$ & 1.18 & 1.18 & - \\
\hline 40 & Luxembourg & 9 & 5 & 4 & $1989-2000$ & 1.41 & 1.44 & 1.36 \\
\hline 41 & Malaysia & 300 & 289 & 11 & $1989-2000$ & 1.70 & 1.69 & 1.85 \\
\hline 42 & Mauritius & 7 & 7 & 0 & $1997-2000$ & 1.12 & 1.12 & - \\
\hline 43 & Mexico & 96 & 37 & 59 & $1989-2000$ & 1.18 & 1.03 & 1.25 \\
\hline 44 & Netherlands & 145 & 110 & 35 & $1989-2000$ & 1.63 & 1.51 & 2.05 \\
\hline 45 & New Zealand & 53 & 44 & 9 & $1989-2000$ & 1.46 & 1.41 & 1.78 \\
\hline 46 & Nigeria & 15 & 15 & 0 & $1992-2000$ & 1.27 & 1.27 & - \\
\hline 47 & Norway & 147 & 128 & 19 & $1989-2000$ & 1.60 & 1.61 & 1.52 \\
\hline 48 & Pakistan & 80 & 77 & 3 & $1989-2000$ & 1.30 & 1.30 & 1.10 \\
\hline 49 & Panama & 1 & 0 & 1 & $1995-2000$ & 1.46 & - & 1.46 \\
\hline 50 & Papua New Guinea & 1 & 0 & 1 & $1996-1998$ & 1.20 & - & 1.20 \\
\hline 51 & Peru & 26 & 21 & 5 & $1992-2000$ & 1.14 & 0.90 & 1.75 \\
\hline 52 & Philippines & 65 & 54 & 11 & $1989-2000$ & 1.40 & 1.37 & 1.51 \\
\hline 53 & Poland & 46 & 38 & 8 & $1992-2000$ & 1.26 & 1.24 & 1.34 \\
\hline 54 & Portugal & 64 & 58 & 6 & $1989-2000$ & 1.06 & 1.06 & 0.96 \\
\hline 55 & Romania & 8 & 8 & 0 & $1997-2000$ & 0.91 & 0.91 & - \\
\hline 56 & Russia & 15 & 4 & 11 & $1996-2000$ & 1.00 & 0.99 & 1.01 \\
\hline 57 & Saudi Arabia & 10 & 10 & 0 & $1997-2000$ & 1.11 & 1.11 & - \\
\hline 58 & Senegal & 1 & 1 & 0 & $1998-2000$ & 1.27 & 1.27 & - \\
\hline 59 & Singapore & 171 & 158 & 13 & $1989-2000$ & 1.45 & 1.42 & 1.79 \\
\hline 60 & Slovak Republic & 7 & 5 & 2 & $1996-2000$ & 0.73 & 0.66 & 0.90 \\
\hline 61 & Slovenia & 8 & 8 & 0 & $1996-2000$ & 0.86 & 0.86 & - \\
\hline 62 & South Africa & 232 & 196 & 36 & $1989-2000$ & 1.53 & 1.50 & 1.70 \\
\hline 63 & South Korea & 327 & 302 & 25 & $1989-2000$ & 1.04 & 1.03 & 1.10 \\
\hline 64 & Spain & 123 & 116 & 7 & $1989-2000$ & 1.28 & 1.28 & 1.36 \\
\hline 65 & Sri Lanka & 11 & 10 & 1 & $1993-2000$ & 1.16 & 1.16 & 1.15 \\
\hline 66 & Sweden & 189 & 162 & 27 & $1989-2000$ & 1.59 & 1.57 & 1.68 \\
\hline 67 & Switzerland & 139 & 120 & 19 & $1989-2000$ & 1.37 & 1.29 & 1.87 \\
\hline 68 & Taiwan, Province of China & 187 & 157 & 30 & $1989-2000$ & 1.65 & 1.58 & 2.04 \\
\hline 69 & Thailand & 171 & 160 & 11 & $1989-2000$ & 1.28 & 1.24 & 1.87 \\
\hline 70 & Tunisia & 3 & 3 & 0 & $1997-2000$ & 1.47 & 1.47 & - \\
\hline 71 & Turkey & 67 & 61 & 6 & $1989-2000$ & 2.03 & 1.97 & 2.51 \\
\hline 72 & Ukraine & 3 & 2 & 1 & $1997-2000$ & 0.80 & 0.66 & 1.03 \\
\hline 73 & Venezuela & 12 & 3 & 9 & $1989-2000$ & 0.89 & 0.68 & 0.93 \\
\hline \multirow[t]{2}{*}{74} & Zimbabwe & 6 & 5 & 1 & $1994-2000$ & 0.85 & 0.88 & 0.67 \\
\hline & Total & 9,096 & 7,926 & 1,170 & & 1.41 & 1.39 & 1.55 \\
\hline
\end{tabular}




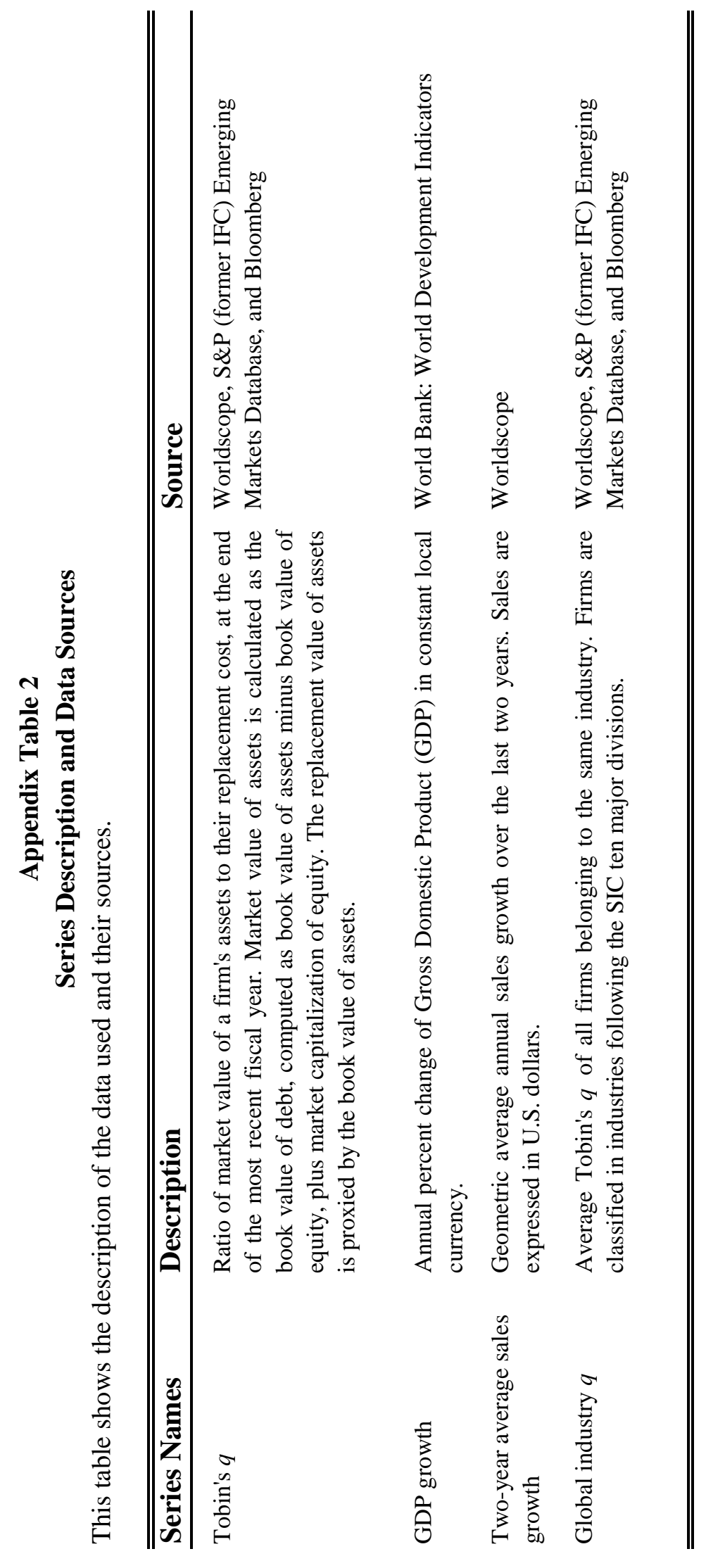

